\title{
OMI air-quality monitoring over the Middle East
}

\author{
Michael P. Barkley ${ }^{1}$, Gonzalo González Abad ${ }^{2}$, Thomas P. Kurosu ${ }^{3}$, Robert Spurr ${ }^{4}$, Sara Torbatian ${ }^{5}$, and \\ Christophe Lerot $^{6}$ \\ ${ }^{1}$ Earth Observation Science Group, Department of Physics and Astronomy, University of Leicester, Leicester, UK \\ ${ }^{2}$ Atomic and Molecular Physics Division, Harvard-Smithsonian Center for Astrophysics, Cambridge, Massachusetts, USA \\ ${ }^{3}$ NASA Jet Propulsion Laboratory, Pasadena, California, USA \\ ${ }^{4}$ RT Solutions Inc, Cambridge, Massachusetts, USA \\ ${ }^{5}$ Air Quality Meteorologist, Air Quality Control Company (AQCC), Tehran, Iran \\ ${ }^{6}$ Belgian Institute for Space Aeronomy (BIRA-IASB), Brussels, Belgium
}

Correspondence to: Michael P. Barkley (mpb14@le.ac.uk)

Received: 30 August 2016 - Discussion started: 4 October 2016

Revised: 13 February 2017 - Accepted: 17 March 2017 - Published: 11 April 2017

\begin{abstract}
Using Ozone Monitoring Instrument (OMI) trace gas vertical column observations of nitrogen dioxide $\left(\mathrm{NO}_{2}\right)$, formaldehyde $(\mathrm{HCHO})$, sulfur dioxide $\left(\mathrm{SO}_{2}\right)$, and glyoxal (CHOCHO), we have conducted a robust and detailed time series analysis to assess changes in local air quality for over 1000 locations (focussing on urban, oil refinery, oil port, and power plant targets) over the Middle East for 2005-2014. Apart from $\mathrm{NO}_{2}$, which is highest over urban locations, average tropospheric column levels of these trace gases are highest over oil ports and refineries. The highest average pollution levels over urban settlements are typically in Bahrain, Kuwait, Qatar, and the United Arab Emirates.

We detect 278 statistically significant and real linear $\mathrm{NO}_{2}$ trends in total. Over urban areas $\mathrm{NO}_{2}$ increased by up to $12 \% \mathrm{yr}^{-1}$, with only two locations showing a decreasing trend. Over oil refineries, oil ports, and power plants, $\mathrm{NO}_{2}$ increased by about 2-9\% $\mathrm{yr}^{-1}$. For HCHO, 70 significant and real trends were detected, with $\mathrm{HCHO}$ increasing by $2-$ $7 \% \mathrm{yr}^{-1}$ over urban settlements and power plants and by about $2-4 \% \mathrm{yr}^{-1}$ over refineries and oil ports. Very few $\mathrm{SO}_{2}$ trends were detected, which varied in direction and magnitude (23 increasing and 9 decreasing). Apart from two locations where $\mathrm{CHOCHO}$ is decreasing, we find that glyoxal tropospheric column levels are not changing over the Middle East. Hence, for many locations in the Middle East, OMI observes a degradation in air quality over 2005-2014. This study therefore demonstrates the capability of OMI to generate long-term air-quality monitoring at local scales over this region.
\end{abstract}

\section{Introduction}

It is well established that poor air quality can significantly impact human health, ecosystems and agriculture, the built environment, and regional climate (Monks et al., 2009). The human and monetary costs associated with increasing levels of air pollution are substantial. For example, the World Health Organization estimates that globally nearly 7 million premature deaths were attributed to household and ambient air pollution during 2012 (WHO, 2014). Similarly, the Organisation for Economic Co-operation and Development estimated that outdoor air pollution is costing its 34 member states, plus the People's Republic of China and India, an estimated USD 3.5 trillion a year in terms of the value of lives lost and ill health (OCED, 2014).

Regulatory control of urban air quality is typically most effective when important target areas are extensively monitored, so pollutant emissions can be quantified and their atmospheric chemical processing well understood. In addition to in situ measurements made by ground stations and aircraft campaigns, satellite observations also form an important component of air-quality monitoring (Martin, 2008; Duncan et al., 2014). Satellite measurements of pollutants, such as nitrogen dioxide $\left(\mathrm{NO}_{2}\right)$, carbon monoxide $(\mathrm{CO})$, tropospheric ozone $\mathrm{O}_{3}$, formaldehyde $(\mathrm{HCHO})$, sulfur dioxide $\left(\mathrm{SO}_{2}\right)$, and aerosol particulate matter $(\mathrm{PM})$, have been widely used to characterise their global atmospheric distributions, to quantify surface precursor emissions, and to evaluate local air quality (see e.g. Martin, 2008; Streets et al., 2013; 
Duncan et al., 2014, and references therein). Furthermore, with the advent of successive and longer-duration satellite missions, particularly the sequence of ultraviolet-visible (UV-VIS) instruments of GOME (Global Ozone Monitoring Experiment) (Burrows et al., 1999), SCIAMACHY (Scanning Imaging Absorption Spectrometer for Atmospheric CHartographY) (Bovensmann et al., 1999), and GOME-2 (Callies et al., 2006), together with the OMI (Ozone Monitoring Instrument) sensor (Levelt et al., 2006), there is a growing ability to study long-term changes in air quality from space. Some notable studies that have used satellite trace gas measurements to examine air-pollution trends include Richter et al. (2005), van der A et al. (2006, 2008), Ghude et al. (2008), De Smedt et al. (2010, 2015), Russell et al. (2012), Schneider and van der A (2012), Hilboll et al. (2013), Jin and Holloway (2015), Krotkov et al. (2016), Lamsal et al. (2015), Lelieveld et al. (2015), Schneider et al. (2015), and Duncan et al. (2016).

The Middle East is a region where long-term changes in air quality have probably been less well studied, in comparison to Asia, Europe, and North America. Besides frequent dust storms (Furman and Hadar, 2003), the region's air quality is characterised by year-long high ozone levels (Lelieveld et al., 2009), with an observed summer maximum (Liu et al., 2009; Zanis et al., 2014). The high ozone levels are in part due to long-range transport, strong local emissions, and favourable conditions for ozone photochemistry (Lelieveld et al., 2009). In situ instruments frequently record high pollutant concentrations in urban areas which exceed recommended guidelines (e.g. Modarres and Dehkordi, 2005; Nasralla and Seroji, 2007; Abdul-Wahab, 2009; Munir et al., 2013; Rashki et al., 2013).

The severity and variability of the region's air pollution can be directly observed from space. For example, several studies have reported appreciable trends in $\mathrm{NO}_{2}$ vertical column over Middle Eastern cities prior to 2011, with increases of the order of $2-9 \% \mathrm{yr}^{-1}$ found over Tehran, $4-5 \% \mathrm{yr}^{-1}$ over Jeddah, $6-7 \% \mathrm{yr}^{-1}$ over Riyadh, and $10-20 \% \mathrm{yr}^{-1}$ over Baghdad, depending on the satellite instrument and the averaging period (van der A et al., 2008; Schneider and van der A, 2012; Hilboll et al., 2013). Similarly, De Smedt et al. (2010) also found an increasing trend of $1-3 \% \mathrm{yr}^{-1}$ in GOME and SCIAMACHY tropospheric HCHO columns over Tehran and Baghdad during 1997-2009 but a decrease of about $2 \% \mathrm{yr}^{-1}$ over Riyadh.

More recently, Lelieveld et al. (2015) examined annual changes in OMI $\mathrm{NO}_{2}$ and $\mathrm{SO}_{2}$ columns over the Middle East over 2005-2014, reporting that, after increases in the period 2005-2010, there was a reduction in these gases, either due to new regulatory legislation or due to falls in economic output associated with regional conflicts and geopolitical controls. In particular, decreases in $\mathrm{NO}_{2}$ tropospheric columns of the order of 40-50\% were noted over Damascus and Aleppo since 2011, coinciding with the start of Syria's civil war. A similar regional-scale study by Krotkov et al.
(2016) also observed that during 2005-2008 $\mathrm{OMI} \mathrm{NO}_{2}$ column increased by $20 \%$ but remained approximately constant thereafter, whereas OMI SO $\mathrm{S}_{2}$ columns dropped by $20 \%$ after 2010 , only recovering to 2005 levels in 2014. A further OMI $\mathrm{NO}_{2}$ column trend analysis over the region's major cities by Duncan et al. (2016) likewise reported decreases over Damascus and Aleppo, but of about 3-4\% $\mathrm{yr}^{-1}$, with increases of about 2-6\% $\mathrm{yr}^{-1}$ elsewhere.

However, besides these valuable studies, to the best of our knowledge, long-term changes in local air quality for many smaller Middle Eastern cities and towns have not been reported. In this study we aim to remedy this situation by determining the changes in air pollution over local population centres and also oil/energy infrastructure from space using a decade's worth of observations from the OMI instrument. Our target areas are therefore (1) cities and towns, (2) largescale oil refineries and ports, and (3) coal, gas and oil-fuelled electricity generating power plants.

To track the air quality over our specified targets, we use OMI tropospheric vertical column observations of $\mathrm{NO}_{2}$, $\mathrm{HCHO}$, and glyoxal (CHOCHO), together with retrieved boundary layer column concentrations of $\mathrm{SO}_{2}$. Although each of these reactive species has different sources and sinks, they are all established key indicators of anthropogenic emissions, active photochemistry, and air pollution. For example, the dominant sources of $\mathrm{NO}_{x}\left(=\mathrm{NO}+\mathrm{NO}_{2}\right)$ in the troposphere are the combustion of fossil fuels, biomass burning, emissions from soil, and lightning. Boundary layer $\mathrm{SO}_{2}$ is predominantly generated by the burning of sulfur-laden fossil fuels and the refinement of sulfur ores; volcanic $\mathrm{SO}_{2}$ emissions are typically injected high into the atmosphere, well above the boundary layer. The chemical reactions of $\mathrm{NO}_{2}$ and $\mathrm{SO}_{2}$ lead to the formation of nitrate and sulfate aerosols, which contribute to $\mathrm{PM}_{2.5}$ (particulate matter with diameters $<2.5 \mu \mathrm{m}$ ), another critical pollutant (Kim et al., 2015). $\mathrm{HCHO}$ and $\mathrm{CHOCHO}$ are reaction products from the oxidation of anthropogenic, biogenic, and pyrogenic volatile organic compounds (VOCs); they can also be directly emitted from fires. Observed $\mathrm{HCHO}$ and $\mathrm{CHOCHO}$ distributions, therefore, contain the signature of underlying VOC emissions. Quantifying VOC emissions is important, as the oxidation of VOCs in the presence of high $\mathrm{NO}_{x}$ and sunlight leads to the formation of tropospheric ozone, which is a major air pollutant contributing to photochemical smog as well as a key greenhouse gas and atmospheric oxidant (Monks et al., 2015). Apart from $\mathrm{SO}_{2}$, which has a lifetime of about 1 week, the trace gases are also relatively short lived (of the order of hours to a day), so the spatial displacements from emission sources are often small.

In this study, we have two broad goals: (1) to establish which locations have the highest pollution levels and (2) to use time series analysis in order to determine which locations have statistically significant trends and to quantify the trend magnitudes. The structure of this paper is as follows. In Sect. 2 we introduce the OMI data products. In Sect. 3 we 
discuss how the OMI data is gridded and describe the time series analysis. We present our results in Sect. 4, with a discussion on their validity in Sect. 5. Finally, we conclude the paper in Sect. 6.

\section{OMI satellite data}

\subsection{The Ozone Monitoring Instrument (OMI)}

The Dutch-Finnish Ozone Monitoring Instrument (Levelt et al., 2006) is a nadir-viewing UV-VIS 2-dimensional charge-coupled device (CCD) spectrometer, launched on board NASA's Aura satellite in July 2004. OMI orbits the Earth in a Sun-synchronous polar orbit, crossing the Equator at 13:30 local time (LT) in its ascending mode. The instrument has a $114^{\circ}$ field-of-view producing a $2600 \mathrm{~km}$ wide swath which contains 60 cross-track pixels that range in size from $14 \times 26 \mathrm{~km}^{2}$ at nadir to $28 \times 160 \mathrm{~km}^{2}$ at the swath edges. With these viewing geometry and orbital characteristics, OMI achieves global coverage daily (in nominal operational mode). However, from 2007 onwards, OMI's coverage has been considerably reduced due to problems with certain rows of its CCD detector (see Sect. 3.1 for further details).

In this work we use 10 years (2005-2014) of OMI vertical column observations of $\mathrm{NO}_{2}, \mathrm{HCHO}, \mathrm{CHOCHO}$, and $\mathrm{SO}_{2}$. A brief overview of these products is given below; explicit details of each trace gas retrieval are given in the cited references.

\subsection{SAO formaldehyde}

The official NASA HCHO product is provided by the updated Smithsonian Astrophysical Observatory (SAO) retrieval, as described in González Abad et al. (2015) and evaluated in Zhu et al. (2016). HCHO slant columns are retrieved through a direct non-linear least-squares fitting of spectral radiances within the interval $328.5-356.5 \mathrm{~nm}$. The retrieval algorithm includes dynamic calibration of solar and radiance wavelengths, the use of a daily radiance reference spectra, an under-sampling correction, and computation of commonmode residual spectrum. The cross sections of $\mathrm{HCHO}$ and other absorbers are fitted, together with a Ring effect correction, scaling and closure polynomials, and a spectral shift parameter. The retrieved slant columns are converted to vertical columns using air mass factors (AMFs) taken from lookup tables pre-computed using the VLIDORT radiative transfer model (Spurr, 2008), which uses a priori HCHO profiles from a global $2.0^{\circ} \times 2.5^{\circ}$ GEOS-Chem chemistry transport model simulation (originally described in Bey et al., 2001). Effective cloud fraction (CFR) and cloud-top pressure (CTP) are taken from the $\mathrm{OMI} \mathrm{O}_{2}-\mathrm{O}_{2}$ cloud product (Acarreta et al., 2004), whilst the surface reflectivity for clear-sky scenes is extracted from the OMI mode Lambertian equivalent reflectivity dataset created by Kleipool et al. (2008). A daily post-processing normalisation correction (a function of latitude and detector row) is applied to reduce retrieval biases, minimise noise, and reduce cross-track striping. Observations with effective cloud fractions $>20 \%$ are rejected. Over our domain of interest $\left(20-80^{\circ} \mathrm{E}, 10-50^{\circ} \mathrm{N}\right)$ we find that the median uncertainty of a single measurement is about $60-70 \%$, with an interquartile range (IQR) of about $175 \%$.

\subsection{DOMINO $\mathrm{NO}_{2}$ vertical columns}

Tropospheric $\mathrm{NO}_{2}$ vertical columns are from the KNMI DOMINO v2 product (Boersma et al., 2011a, b), which is a well-established dataset (see e.g. Hains et al., 2010; Wang et al., 2016). The $\mathrm{NO}_{2}$ slant columns are retrieved using the differential optical absorption spectroscopic (DOAS) technique by fitting the absorption cross sections of $\mathrm{NO}_{2}, \mathrm{O}_{3}$, and $\mathrm{H}_{2} \mathrm{O}$, along with a synthetic Ring spectrum, to observed reflectance spectra in the $405-465 \mathrm{~nm}$ interval (Boersma et al., 2007). The retrieved total slant columns are then assimilated into the TM4 chemistry model (Dentener et al., 2003), to estimate and remove the stratospheric $\mathrm{NO}_{2}$ component. Finally, tropospheric vertical columns are then derived by applying altitude-resolved AMFs from a pre-computed lookup generated with the KNMI DAK radiative transfer model using TM4 $\mathrm{NO}_{2}$ profiles from a $2.0^{\circ} \times 3.0^{\circ}$ global simulation. Surface reflectivity and cloud parameters are taken from Kleipool et al. (2008) and Acarreta et al. (2004), respectively. As with $\mathrm{HCHO}$, observations with effective cloud fractions $>20 \%$ are rejected. The median uncertainty of an individual measurement over our target region is about $60-70 \%$, with an IQR of about $54 \%$.

\subsection{BIRA CHOCHO vertical columns}

Glyoxal vertical columns are retrieved from OMI spectra using an updated DOAS retrieval originally devised for GOME-2 (Lerot et al., 2010). The retrieval uses a daily mean Earthshine Pacific Ocean radiance spectrum and applies a row-dependent wavelength calibration. An initial pre-fit of liquid water optical depth (in 405-490 nm) is performed, before the absorption cross sections of CHOCHO and other interfering absorbers are fitted in the spectral window 435$490 \mathrm{~nm}$ to retrieve the slant columns. Tropospheric vertical columns are obtained using pre-computed look-up tables of altitude-resolved AMFs, which use a priori profiles over land from a global $2.0^{\circ} \times 2.5^{\circ}$ IMAGES simulation (Müller and Stavrakou, 2005). Over the oceans a single oceanic profile is used for the AMFs, derived from airborne MAX-DOAS (multi axis differential optical absorption spectroscopy) measurements over the Pacific Ocean (Volkamer et al., 2015). Unlike the retrievals of $\mathrm{HCHO}$ and $\mathrm{NO}_{2}$, the cloud effects are not accounted for in the AMF calculation (via the independent pixel approximation); instead, only clear-sky observations are retained by rejecting scenes with effective cloud fractions $>20 \%$. The median uncertainty of an individual measurement is about $50-60 \%$, with an IQR of about $250 \%$. 


\subsection{NASA sulfur dioxide}

To assess changes in anthropogenic $\mathrm{SO}_{2}$, we use planetary boundary layer (PBL) columns (NASA product OMSO2 v1.2.0) determined using a principal component analysis (PCA) retrieval that is sensitive to surface concentrations $(\mathrm{Li}$ et al., 2013). The algorithm applies the PCA technique to OMI UV Sun-normalised radiances $(310.5-340 \mathrm{~nm})$ over an $\mathrm{SO}_{2}$-free region (in the equatorial Pacific) to establish the principal components of the main physical and measurement spectral features that do not correspond to $\mathrm{SO}_{2}$ absorption. A set of principal components and $\mathrm{SO}_{2}$ radiance Jacobians (i.e. that describe the radiance sensitivities to changes in the $\mathrm{SO}_{2}$ column) are then iteratively fitted to observed OMI radiances to obtain the slant column density. An estimate of the boundary layer $\mathrm{SO}_{2}$ is then calculated based on the assumptions of the vertical $\mathrm{SO}_{2}$ distribution (Krotkov, 2014). The algorithm applies the PCA technique to each OMI detector row individually and uses the VLIDORT radiative transfer code to compute the $\mathrm{SO}_{2}$ Jacobians, with RT model inputs based on a fixed atmospheric profile and climatological $\mathrm{SO}_{2}$ profile over the summertime eastern US, the latter corresponding to an effective AMF of 0.36 (Fioletov et al., 2016). Scenes with strong ozone absorption of $>1500$ Dobson units $\left(1 \mathrm{DU}=2.69 \times 10^{16}\right.$ molecules $\left.\mathrm{cm}^{-2}\right)$ are excluded due to spectral interference in the retrieval. For this study we only use $\mathrm{SO}_{2}$ data from OMI rows 4-54 (0-based) and with a cloud radiance fraction $<0.3$ (Krotkov, 2014), which corresponds to an effective cloud fraction of about $15 \%$ (Krotkov et al., 2016), broadly consistent with the other species. Although $\mathrm{SO}_{2}$ over the Middle East is mostly unaffected by volcanic emissions over 2005-2014 (Krotkov et al., 2016), transient volcanic $\mathrm{SO}_{2}$ enhancements were removed if they exceeded a threshold of 5 DU (Fioletov et al., 2011). The estimated uncertainty of the $\mathrm{SO}_{2} \mathrm{PBL}$ is about $0.5 \mathrm{DU}$ in the tropics and $\sim 0.7-0.9$ at higher latitudes, based on the analysis of the root mean square (RMS) and standard deviation values for instantaneous field-of-view (IFOV) observations in different latitudinal bands (see Li et al., 2013; Krotkov, 2014).

\section{Methods}

\subsection{Data gridding}

We monthly average the OMI observations onto a highresolution $0.05^{\circ} \times 0.05^{\circ}$ grid using an area-weighting tessellation algorithm (Spurr, 2003; Hewson et al., 2015). The gridding algorithm properly accounts for the areal proportions of grid cells underlying the satellite footprint and inversely weights each observation according to the measurement uncertainty and OMI ground pixel size. Spatial zoom orbits are not included in our analyses, nor are scenes with solar zenith angles $>70^{\circ}$. We also fol- low the data recommendations provided with each product to reject non-optimum observations. The quality of the level 1B radiance data from certain rows of OMI's CCD detector is known to be affected by blockage effects, wavelength shifts, and stray light originating from outside the nominal field of view. This dynamic behaviour is the well-known OMI row anomaly (http://www.knmi.nl/omi/ research/product/rowanomaly-background.php), which impacts atmospheric retrievals from the affected rows. The temporal variability of the row anomaly is also known to compromise the derivation of long-term trace gas trends (De Smedt et al., 2015). For this reason, we follow a similar approach to De Smedt et al. (2015), by using the OMI XTrackQualityFlags (Dutch Space, 2009) to construct a static mask based on the most affected rows at the end of 2013 , to then discard row-anomaly observations over the entire 2005-2014 period. This quality filtering largely removes any statistically significant sampling trends in the generated monthly datasets, except for the SAO HCHO and DOMINO $\mathrm{NO}_{2}$ data. Therefore, for these gases we further use the XTrackQualityFlags to identify affected observations not flagged by the static mask, whose measurement uncertainties we then increase by a factor of 1000 , so that these observations are included in the analysis without affecting the monthly averaged fields (i.e. they are assigned a very low weight in the averaging). On average there are typically 20-35 samples per grid cell per month. To reduce noise in the monthly gridded data, we smooth the data with a $0.15^{\circ} \times 0.15^{\circ}$ Gaussian filter of $1 \sigma$ width. For the noisier $\mathrm{CHOCHO}$ fields, a $2 \sigma$ Gaussian is used. The spatial smoothing enhances localised "hot spots" and is preferable to averaging the data onto a coarser-resolution grid where the atmospheric signatures of target features can be lost. The median uncertainties of the gridded data are about $4 \%$ for $\mathrm{NO}_{2}, 6 \%$ for $\mathrm{HCHO}, 27 \%$ for $\mathrm{CHOCHO}$, and $40 \%$ for $\mathrm{SO}_{2}$.

Figure 1 shows the 2005 annual distributions of each species over the broad Middle East region. Clearly visible in the $\mathrm{NO}_{2}, \mathrm{HCHO}$, and $\mathrm{CHOCHO}$ maps are the major urban areas of Riyadh, Baghdad, Tehran, Jeddah, and pollution enhancements along the eastern and northern coasts of the Persian Gulf. Intense $\mathrm{SO}_{2}$ hotspots are found over the Jeddah and Mecca region, Kharg Island (in the Gulf), and near Kerman (Iran), where the Sarcheshmeh Copper Complex smelter is found.

\subsection{Time series construction}

To determine the temporal variability of the OMI vertical column data over urban areas we use the Global Rural-Urban Mapping Project Version 1 (GRUMP v1) settlement points database (Balk et al., 2006; SEDAC, 2015) to identify the geolocation coordinates of 818 cities and towns that have populations ranging from over 50 to nearly 7 million inhabitants (as determined for the year 2000). We then construct a 10 -year time series (of 120 months) by averaging 

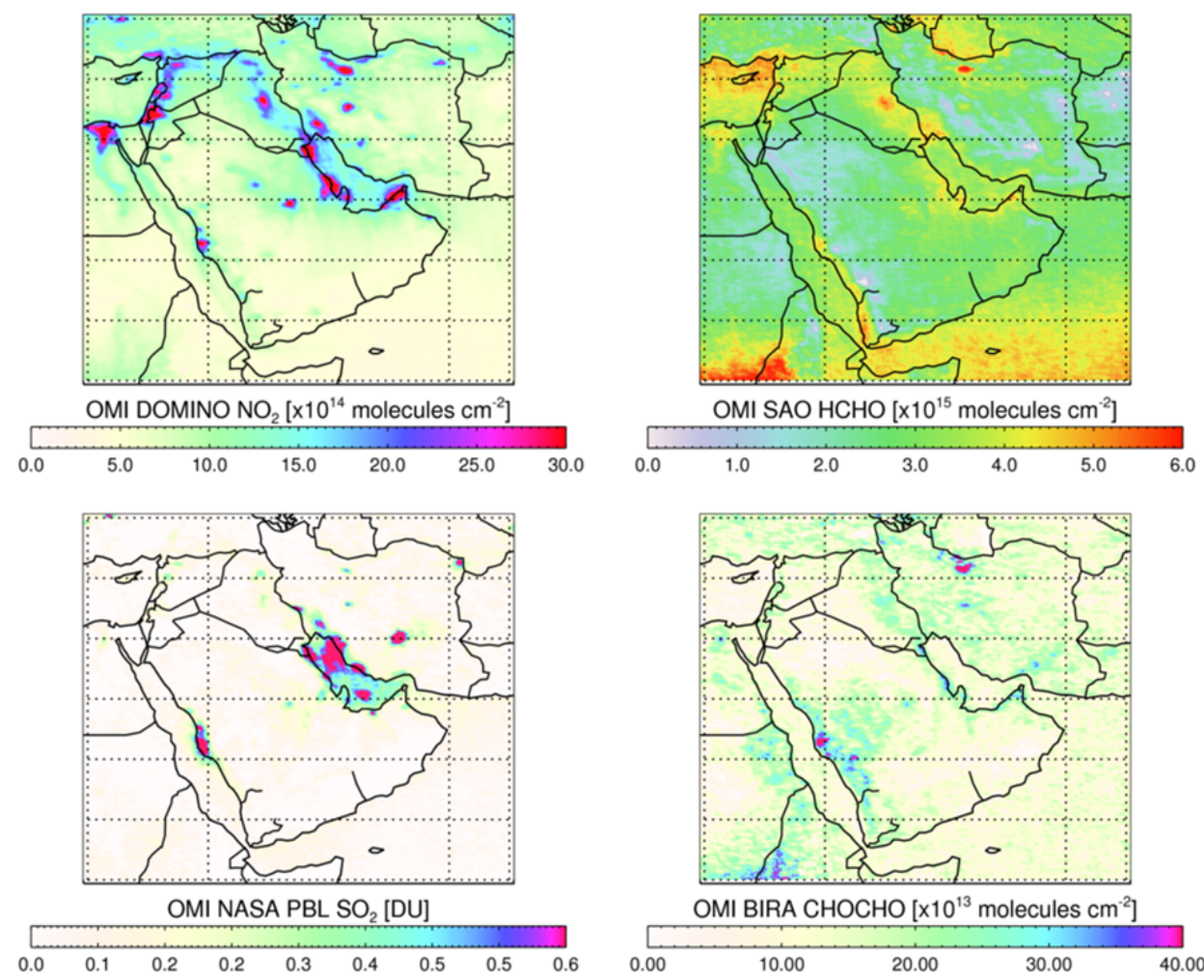

Figure 1. The OMI 2005 annual mean distributions of $\mathrm{NO}_{2}, \mathrm{HCHO}, \mathrm{SO}_{2}$, and $\mathrm{CHOCHO}$. The OMI data have been averaged onto a $0.05^{\circ} \times 0.05^{\circ}$ grid using observations with cloud fractions $<20 \%$ and solar zenith angles $\leq 70^{\circ}$. Observations affected by the row anomaly are excluded, as described in Sect. 3.1, and the gridded data have been smoothed with a $0.15^{\circ} \times 0.15^{\circ}$ Gaussian filter of $1 \sigma$ width $(2 \sigma$ for CHOCHO).

those monthly gridded data that lie within \pm 2 grid cells of the city or town location, which corresponds to a radial distance of approximately $10 \mathrm{~km}$ from the urban centre. Visual inspection of these spatial masks overlaid onto Google Earth imagery shows this filtering criteria is well suited to capture the extent of most urban areas (see e.g. Fig. S1 in the Supplement). For Baghdad, Riyadh, and Tehran, which have larger urban spread, the average of \pm 4 grid cells is used instead, consistent with an approximate $20 \mathrm{~km}$ radial distance. In addition to the trace gas vertical columns, we also construct coincident time series for the associated cloud fraction, cloud-top pressure (or height), AMFs (where appropriate), and number of grid-cell samples. This helps clarify whether any observed trends in the trace gases are real, by applying the same time series analysis to all the retrieved parameters.

We use this same approach to examine air-quality variability over oil refineries, oil ports, and power plants. The 2010 Oil Refining Survey (Kootungal, 2010) was used to identify 41 major crude oil refineries, whereas the Global Energy Observatory (GEO) free online resource (http:// globalenergyobservatory.org) was used to locate 18 oil ports and 155 power plants. Where different types of power plants (e.g. oil versus gas fuelled) were closely co-located, a single geolocation coordinate was used to mark that target. The geographical distribution of the selected targets is shown in Fig. 2 (left panel), and, as an example, Fig. 2 (right panel) shows the urban spatial filtering masks, applied to the observed 2005 annual $\mathrm{OMI} \mathrm{NO}_{2}$ distributions over northern Iran. The latter figure shows that this approach treats the larger cities, such as Tehran, as individual urban regions, with intention of resolving trends of separate districts, and that in some cases the spatial masks can partially overlap for targets which are close to one another.

Considering all locations, we find that by applying a weighted average to the data within \pm 2 grid cells of the target, the median uncertainties of the trace gas vertical column time series data points reduce to $0.37 \pm 0.26 \%$ for $\mathrm{NO}_{2}$, $0.73 \pm 0.64 \%$ for $\mathrm{HCHO}, 1.82 \pm 1.90 \%$ for $\mathrm{CHOCHO}$, and $1.63 \pm 2.58 \%$ for $\mathrm{SO}_{2}$.

\subsection{Time series analysis}

Each time series consists of monthly mean OMI observations, $y(t)$, over a given target site, where time $t$ is in fractional years. We analyse each time series individually for each location following a consistent procedure. First, we filter the time series data for outliers, rejecting observations that lie beyond 2.5 median absolute standard deviations (Leys 


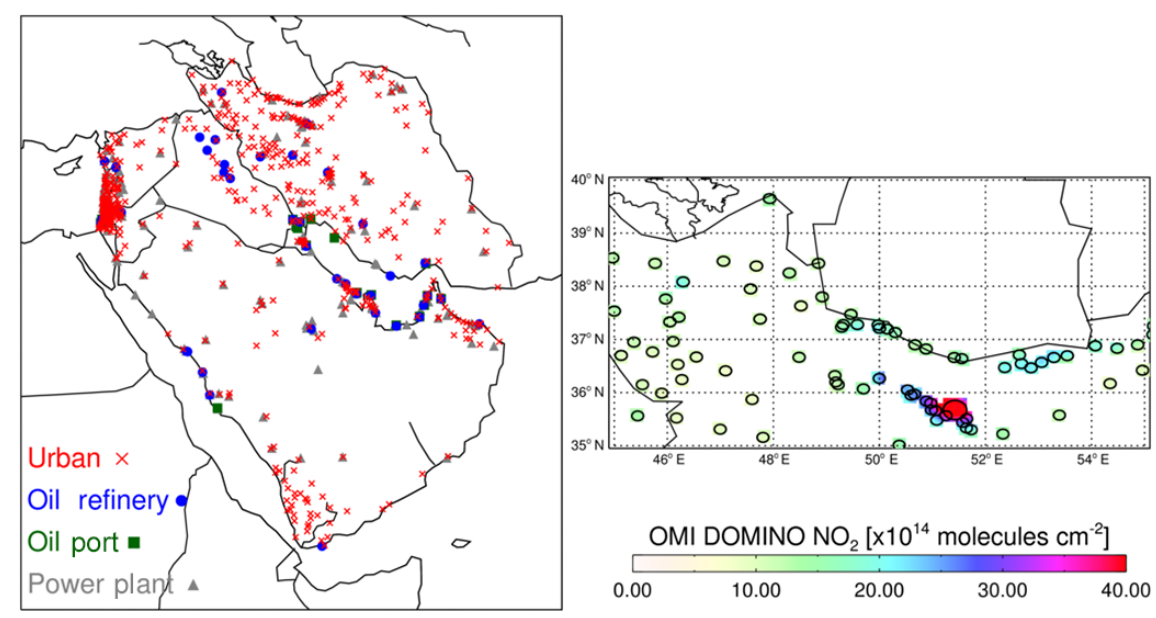

Figure 2. (Left) The geographical distributions of the target locations showing cities and towns (in red) as specified by the GRUMP v1 settlement point data base (Balk et al., 2006; SEDAC, 2015), oil refineries (in blue) (based on Kootungal, 2010), and oil ports and power plants based on the Global Energy Observatory (GEO) online resource (http://globalenergyobservatory.org). (Right) $\mathrm{OMI}_{2005} \mathrm{NO}_{2}$ annual mean of over northern Iran, with a spatial filtering mask applied to extract observations over urban centres (see Sect. 3.2). The OMI data have been averaged onto a $0.05^{\circ} \times 0.05^{\circ}$ grid using observations with cloud fractions $<20 \%$ and solar zenith angles $\leq 70^{\circ}$. Observations affected by the row anomaly are excluded, as described in Sect. 3.1, and have been smoothed with a $0.15^{\circ} \times 0.15^{\circ}$ Gaussian filter of $1 \sigma$ width.

et al., 2013). This helps to reduce difficulties in the analysis and interpretation of noisy vertical column data when encountered; the filtering is not required for AMFs, cloud parameters, or the number of samples. Second, we linearly interpolate across missing data points, applying a quality filter, so that if $>20 \%$ of (randomly scattered) values are missing from the time series, then the dataset is rejected. Typically $0-$ $25 \%$ of data points may be missing from a time series, but, on average, we find that less than $6 \%$ are missing. Third, we then fit to the data a model function, $F(t)$, consisting of a linear component plus a four-term harmonic Fourier series, defined as follows:

$$
\begin{aligned}
F(t) & =\mu+\omega t+\sum_{n=1}^{4}\left[A_{n} \cos (2 \pi n t)\right. \\
& \left.+B_{n} \sin (2 \pi n t)\right],
\end{aligned}
$$

where $\mu$ is the mean value of the time series data at time $t=0, \omega$ is the linear trend of the variable (per year), and the parameters $A_{n}$ and $B_{n}$ are the Fourier series coefficients that essentially model seasonal and inter-seasonal variability. Many other trend studies have fitted very similar functions (see e.g. van der A et al., 2006; Gardiner et al., 2008; De Smedt et al., 2010; Hilboll et al., 2013; Jin and Holloway, 2015). We fit this model to the data using a non-linear least-squares Levenberg-Marquardt algorithm, which generates an estimate of the fit parameters $\mu, \omega, A_{n}$, and $B_{n}$ plus their uncertainties and covariance.

Fourth, we check that the trend $\omega$ is real, i.e. significant at the $95 \%$ confidence level. The generally accepted rule for determining whether a trend is statistically significant is $\left|\omega / \sigma_{\omega}\right|>2$, provided the lag-one autocorrelation of the fit residual is small (Weatherhead et al., 1998; van der A et al., 2006). To determine the precision $\left(\sigma_{\omega}\right)$ of the trend, we follow the approach of Gardiner et al. (2008) by bootstrap resampling (with replacement) the initial fit residuals to reconstruct the fitted function with representative noise. The model function $F(t)$ is then refitted to this data, and the fit parameters are recalculated. This process is repeated 2000 times to build a sampling distribution for each of the fit coefficients, with the difference between the 2.5th and 97.5th percentiles representing the coefficient's associated $2 \sigma$ uncertainty (De Smedt et al., 2010). The advantage of the bootstrap resampling method is that it enables non-normally distributed data to be treated robustly (Gardiner et al., 2008).

Fifth, we additionally filter the initial fit residuals with short- and long-term filters, to derive several other quantities of interest. For this we follow closely the curve fitting routines adopted by the NOAA's Earth System Research Laboratory (ERSL) Global Monitoring Division (GMD), which are based on the original study of Thoning et al. (1989) and are fully described online (at http://www.esrl.noaa.gov/ $\mathrm{gmd} / \mathrm{ccgg} / \mathrm{mbl} / \mathrm{crvfit} / \mathrm{crvfit}$.html). The general approach is to transform the residuals into the frequency domain using a Fast Fourier Transform (FFT), apply a low-pass filter function to the frequency data, and then transform the filtered data to the time domain using an inverse FFT. We use a low-pass frequency filter $H(f)$ of the form

$$
H(f)=\exp \left[-\ln 2 \times\left(\frac{f}{f_{c}}\right)^{6}\right],
$$

where $f$ is the frequency (cycle per year) and $f_{c}$ is the frequency response of the filter. We filter the initial fit residual twice, once with a short-term cut-off value for smooth- 
ing the data and once with a long-term value to remove any remaining seasonal oscillation and to track inter-annual variability. Once the residual has been filtered, several curves can be constructed.

1. A smoothed function fit $F_{\mathrm{S}}(t)$, which is the function fit $F(t)$ plus the residual filtered using the short-term cutoff value. Its uncertainty is given by $\sigma_{F_{\mathrm{S}}}^{2}=\sigma_{F}^{2}+\sigma_{\mathrm{S}}^{2}$, where $\sigma_{\mathrm{S}}$ is the uncertainty of the short-term filtered residual and $\sigma_{F}$ is the uncertainty of the model function estimated from the covariance matrix of the fit parameters using error propagation.

2. A long-term trend fit $F_{\mathrm{T}}(t)$, which is the linear component of $F(t)$ plus the residual filtered using the longterm filter. It represents the long-term trend with the seasonal cycle removed. Its uncertainty is $\sigma_{F_{\mathrm{T}}}^{2}=\sigma_{F}^{2}+\sigma_{\mathrm{L}}^{2}$, where $\sigma_{\mathrm{L}}$ is the uncertainty of the long-term filtered residual.

3. A de-trended seasonal cycle $F_{\mathrm{C}}(t)$, which is computed by subtracting the long-term trend fit from the smoothed function fit, that is, $F_{\mathrm{C}}(t)=F_{\mathrm{S}}(t)-F_{\mathrm{T}}(t)$. It represents the annual seasonal oscillation with any long-term trend removed. Its uncertainty is given by $\sigma_{F_{\mathrm{C}}}^{2}=\sigma_{F_{\mathrm{S}}}^{2}+\sigma_{F_{\mathrm{T}}}^{2}$. The average seasonal amplitude is defined as the mean peak to trough difference of $F_{\mathrm{C}}(t)$.

4. A growth rate curve $F_{\mathrm{G}}(t)$, which is the rate of change of the long-term trend $F_{\mathrm{T}}(t)$, determined using a threepoint (quadratic) Lagrangian interpolation to compute the first derivative. Its uncertainty is given by $\sigma_{\mathrm{G}}^{2}=$ $2 \times \sigma_{F_{\mathrm{T}}}^{2}$ since the derivative is approximately equal to the taking of the difference of two data points 1 year apart and plotting this difference midway between the two points. The average growth rate, $G$, is then simply the median value of $F_{\mathrm{G}}(t)$.

The statistical uncertainty of the residual filters $\left(\sigma_{\mathrm{S}}\right.$ and $\left.\sigma_{\mathrm{L}}\right)$ are calculated following Thoning et al. (1989), via

$\sigma_{\text {filter }}^{2}=\sigma_{\text {rsd }}^{2} \sum_{i=1}^{n_{c}} c_{i}^{2}+2 \sum_{j=1}^{n_{c}-1} \sum_{k=j+1}^{n_{c}} c_{j} c_{k} r_{(k-j)}$,

where $\sigma_{\text {rsd }}$ is the residual standard deviation, $r_{(k-j)}$ are the lags in a first-order auto-regressive process (defined as $r(k)=r(1)^{k}$ for $\left.k=1,2, \ldots\right)$, and $n_{c}$ is the number of filter weights. The filter weights, $c_{i}$, are the values of the impulse response functions of the filter transfer functions, computed by applying the filters to a delta function impulse in the time domain (Thoning et al., 1989). We compute the filter uncertainties for the short- and long-term cut-off values individually and apply them to calculate the uncertainties in the derived curves. In this study, we use short-term and long-term filters for 200 and 667 days, respectively. Sensitivity tests using filters of 100, 150, 500, and 720 days indicate that these two filter values offer the best compromise for slightly higher correlations between the data and fitted curves versus slightly smaller curve uncertainties. Furthermore, we also evaluated the long-term filter values $(500,667$, and 720 days) on the DOMINO $\mathrm{NO}_{2}$ and SAO HCHO products over urban areas (818 targets) to assess their impact on the growth rate (note the filters do not affect the fitted linear trend $\mu$ ). We found differences in the growth rates are small when using the 500 and 720 day filters, compared with the default 667-day filter, e.g. for $\mathrm{NO}_{2}$ the differences are less than $1 \%$, and for $\mathrm{HCHO}$ they are $1-2 \%$.

Figure 3 shows an example of a time series fit to observed $\mathrm{NO}_{2}$ data over Dahuk in Iraq $\left(43.00^{\circ} \mathrm{E}, 36.87^{\circ} \mathrm{N}\right.$, population: 65683 ), where a statistically significant large upward linear trend of $2.77 \pm 0.35 \times 10^{14}$ molecules $\mathrm{cm}^{-2} \mathrm{yr}^{-1}$ is found. This corresponds to a linear growth of $12.23 \pm 1.54 \%$ relative to the observed 2005-2014 median VCD. In this example, $\left|\omega / \sigma_{\omega}\right|=7.9$, and the uncertainties of the trend $\left(F_{\mathrm{T}}\right)$ and smoothed curves $\left(F_{\mathrm{S}}\right)$ are about $5 \%$ and $7.5 \%$, respectively. The median growth rate $G$ is $12.44 \pm 8.18 \% \mathrm{yr}^{-1}$, whilst the mean seasonal amplitude is $1.78 \pm 0.32 \times 10^{15}$ molecules $\mathrm{cm}^{-2}$ (about $79 \pm 14 \%$ relative to the median column). A similar analysis of the coincident time series of the $\mathrm{NO}_{2} \mathrm{AMF}$, cloud fraction, cloud-top pressure, and number of samples reveals no other significant trend. This indicates that the upward growth in $\mathrm{NO}_{2}$ is not caused by a trend in any other retrieval parameter and is real at the $95 \%$ confidence level. This observed increase in $\mathrm{NO}_{2}$ over the city is likely linked to its recent population growth (estimated at 280400 people in 2012, see e.g. MOP-KRG, 2012) and rapid urban expansion (Mustafa et al., 2012). Figures $\mathrm{S} 2$ to $\mathrm{S} 4$ show similar fits for $\mathrm{HCHO}, \mathrm{CHOCHO}$, and $\mathrm{SO}_{2}$, respectively.

Although no underlying trends have been reported in the OMI data (Boersma et al., 2011b; Li et al., 2013; González Abad et al., 2015), as a precaution we performed the time series analysis on gridded OMI data over the remote Pacific Ocean $\left(60^{\circ} \mathrm{N}-60^{\circ} \mathrm{S}, 90-170^{\circ} \mathrm{W}\right)$. No statistically significant trends were found for any species.

\section{Results}

In this section we present our main results, with Tables 1-4 providing a concise summary of the analysis. Tables S1 to S2 (both excel files) in the Supplement provide a more complete classification of the analysis, where the highest ranked median levels and absolute linear trends for each target category are tabulated. Only the top 50 ranked locations are given for urban and power plants categories. 


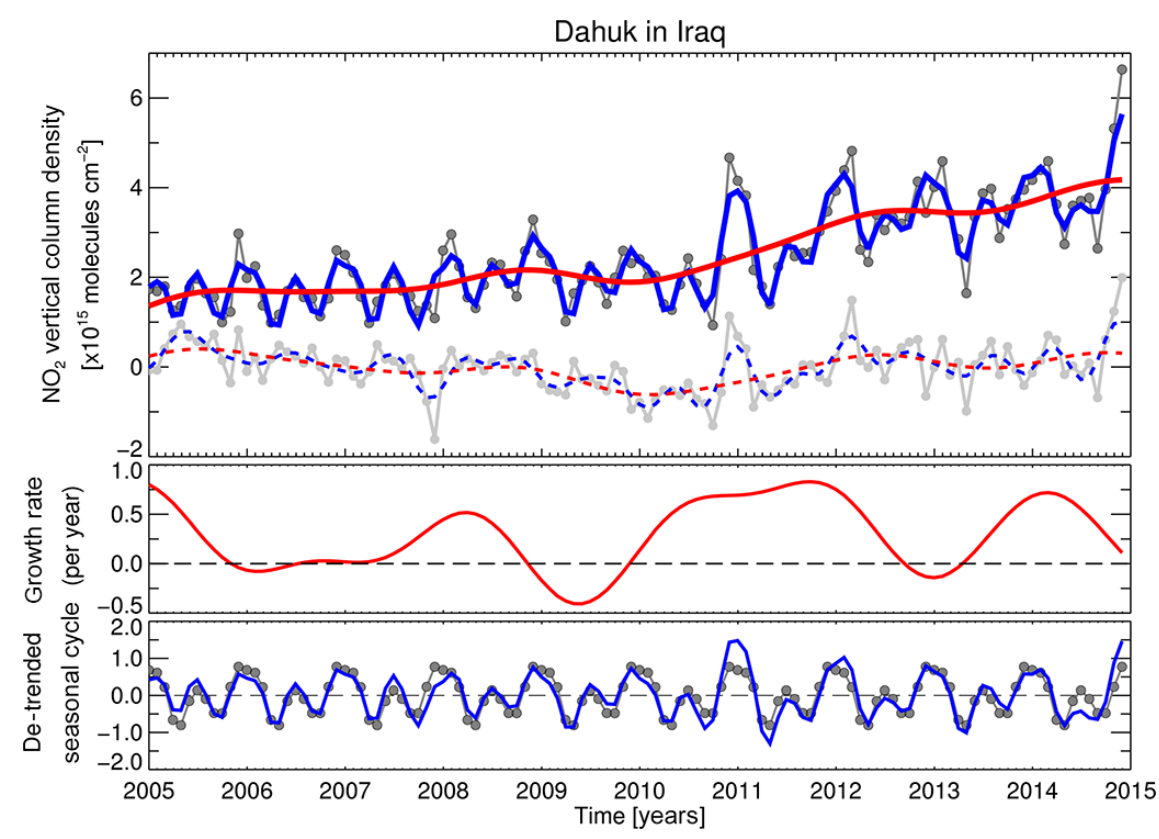

Figure 3. An example of a time series fit to observed $\mathrm{NO}_{2}$ data over Dahuk, Iraq, as outlined in Sect. 3.3. (Top) The monthly OMI NO vertical columns are indicated by dark grey filled circles, whilst the light grey filled circles represent the fitting residual, which has been smoothed with a short-term 200-day filter (dashed blue line) and long-term 667-day filter (red dashed line). The solid red line is the longterm trend $F_{\mathrm{T}}(t)$, given by the linear component of the fitted function $F(t)$ (Eq. 1) plus the residual filtered using the long-term filter. The solid blue line is the smoothed fitted curve $F_{\mathrm{S}}(t)$ given by $F(t)$ plus the residual filtered using the short-term filter. (Middle) The $\mathrm{NO}_{2}$ vertical column growth rate in $\times 10^{15}$ molecules $\mathrm{cm}^{-2} \mathrm{yr}^{-1}$, which is the derivative of the long-term trend $F_{\mathrm{T}}(t)$ shown in the toppanel. (Bottom) The de-trended seasonal cycle $F_{\mathrm{C}}(t)$, which is the difference between the long-term trend and the smoothed function fit (i.e. $F_{\mathrm{S}}(t)-F_{\mathrm{L}}(t)$ ). This represents the annual seasonal oscillation with any long-term trend removed. The dark grey filled circles are the fitted harmonic components of $F(t)$.

\subsection{Average pollution levels}

We use the observed median vertical columns determined for all locations within each category (i.e. not the fitted $\mu$ in Eq. 1) to assess average pollution levels (see Table S1). The overall 2005-2014 average median columns are $26.98 \pm 1.85 \times 10^{14}$ molecules $\mathrm{cm}^{-2}$ for $\mathrm{NO}_{2}, 3.97 \pm 0.30 \times 10^{15}$ molecules $\mathrm{cm}^{-2}$ for $\mathrm{HCHO}$, $18.71 \pm 2.09 \times 10^{13}$ molecules $\mathrm{cm}^{-2}$ for $\mathrm{CHOCHO}$, and $0.21 \pm 0.09 \mathrm{DU}$ for $\mathrm{SO}_{2}$. Relative to the overall median column, the highest mean $\mathrm{NO}_{2}$ values are found over urban areas and oil ports, which are about 5 and $15 \%$ higher than refineries and power plants, respectively. Whereas for $\mathrm{HCHO}$, we find that the highest average columns are found over oil ports, with values about $5 \%$ higher than those for refineries, $15 \%$ higher than urban areas, and $16 \%$ higher than power plants. The highest average $\mathrm{CHOCHO}$ levels are also found over oil ports, with refineries, power plants, and urban areas being about 5,16 , and $25 \%$ less, respectively. For $\mathrm{SO}_{2}$ the highest average values are found over oil ports and refineries, which are $57 \%$ higher than power plants and $81 \%$ higher than urban regions. Hence, the general conclusion we can make is that average trace gas levels tend to be highest over oil ports and refineries (with the exception of $\mathrm{NO}_{2}$ ).
The interquartile range (IQR) of the observed median columns gives some indication of the spread of the trace gas levels within a given target category. For $\mathrm{NO}_{2}$ the IQR varies between $68 \%$ for urban areas, $59 \%$ for refineries, $45 \%$ for oil ports, and $53 \%$ for power plants (as a percentage of the overall average median values). The higher IQR over urban areas may reflect the larger variability of underlying $\mathrm{NO}_{x}$ emissions between different towns and cities. For $\mathrm{HCHO}$, the IQR only varies between $13 \%$ for urban areas and ports, $20 \%$ for refineries, and $26 \%$ for power plants. The similar IQR values likely indicate a lower variation in HCHO sources and sinks over different locations. For CHO$\mathrm{CHO}$, the IQR varies between $25 \%$ for urban areas to $51 \%$ over refineries, with the IQR over ports and plants about 46$47 \%$. For $\mathrm{SO}_{2}$, the IQR is lowest over urban areas $(42 \%)$ but increases substantially over ports $(100 \%)$, power plants $(114 \%)$, and to a maximum over refineries $(148 \%)$.

Figure S4 shows the statistical box-and-whisker plots of the observed median vertical columns over urban targets for each country. The highest average pollution levels are typically found in Bahrain, Kuwait, Qatar, and the United Arab Emirates (UAE). For example, $\mathrm{NO}_{2}$ columns over Bahrain, Kuwait, and the UAE are 52, 66, and $53 \%$ above the median urban level of $28.13 \times 10^{14}$ molecules $\mathrm{cm}^{-2}$, respec- 
Table 1. Statistical summary of the DOMINO $\mathrm{NO}_{2}$ vertical column density (VCD) analysis conducted at an approximate $10 \mathrm{~km}$ radius over the target locations. Statistical values are shown for those locations which have a real VCD trend, i.e. those locations without a corresponding trend in either the air mass factor (AMF), cloud fraction (CFR), cloud-top pressure (CTP), or number of samples (SAM). Values in parentheses correspond to statistics for all locations of a given category. VCD values are given in $10^{14}$ molecules $\mathrm{cm}^{-2}$, and IQR is the interquartile range.

\begin{tabular}{|c|c|c|c|c|}
\hline & Urban & Refinery & Oil ports & Power plants \\
\hline \# locations & 818 & 41 & 18 & 155 \\
\hline \multicolumn{5}{|c|}{ \# locations with trends } \\
\hline VCD & 318 & 32 & 13 & 112 \\
\hline VCD and AMF & 71 & 7 & 2 & 19 \\
\hline VCD and CFR & 24 & 6 & 3 & 19 \\
\hline VCD and CTP & 14 & 5 & 2 & 9 \\
\hline VCD and SAM & 35 & 5 & 2 & 18 \\
\hline VCD only & 198 & 17 & 6 & 57 \\
\hline \multicolumn{5}{|l|}{ Observed VCD } \\
\hline Median & $18.27(28.31)$ & $26.74(27.10)$ & $33.00(28.19)$ & $27.22(24.32)$ \\
\hline IQR & $15.00(18.29)$ & $15.78(15.78)$ & $11.45(12.18)$ & $14.20(14.16)$ \\
\hline Maximum & $136.65(136.65)$ & $87.90(87.90)$ & $64.92(100.72)$ & $189.85(189.85)$ \\
\hline Minimum & $-4.87(-10.61)$ & $-6.63(-6.63)$ & $10.55(5.94)$ & $-6.63(-6.63)$ \\
\hline \multicolumn{5}{|c|}{ Seasonal amplitude } \\
\hline Median & $8.82(12.38)$ & $11.86(11.86)$ & $11.54(11.83)$ & $11.02(10.52)$ \\
\hline IQR & $5.30(8.01)$ & $9.78(8.77)$ & $6.93(5.28)$ & $6.03(6.60)$ \\
\hline Maximum & $38.88(38.88)$ & $33.05(33.05)$ & $18.50(21.30)$ & $46.32(66.32)$ \\
\hline Minimum & $3.07(1.49)$ & $4.62(3.28)$ & $7.05(5.76)$ & $4.34(1.68)$ \\
\hline \multicolumn{5}{|l|}{ Linear trend } \\
\hline Median & $0.58(0.26)$ & $0.84(0.81)$ & $1.05(0.97)$ & $0.89(0.65)$ \\
\hline IQR & $0.48(0.49)$ & $0.69(0.66)$ & $2.16(1.26)$ & $0.45(0.68)$ \\
\hline Maximum & $2.77(3.14)$ & $2.65(2.65)$ & $3.12(3.35)$ & $2.65(3.34)$ \\
\hline Minimum & $-0.75(-0.75)$ & $0.57(-0.23)$ & $0.74(-0.01)$ & $0.25(-0.72)$ \\
\hline \multicolumn{5}{|l|}{ Growth rate } \\
\hline Median & $0.64(0.42)$ & $0.83(0.70)$ & $0.95(0.89)$ & $0.82(0.62)$ \\
\hline IQR & $0.56(0.52)$ & $0.71(0.95)$ & $2.59(1.68)$ & $0.64(0.83)$ \\
\hline Maximum & $2.82(4.89)$ & $1.74(2.55)$ & $3.44(4.31)$ & $2.95(3.91)$ \\
\hline Minimum & $-0.91(-0.98)$ & $0.19(-0.57)$ & $0.51(0.14)$ & $-0.33(-0.84)$ \\
\hline \multicolumn{5}{|l|}{ Median errors } \\
\hline Linear trend & $0.19(0.27)$ & $0.27(0.27)$ & $0.29(0.28)$ & $0.27(0.25)$ \\
\hline Trend curve & $0.80(1.13)$ & $1.13(1.13)$ & $1.20(1.16)$ & $1.14(0.99)$ \\
\hline Smoothed curve & $1.13(1.68)$ & $1.38(1.63)$ & $1.84(1.78)$ & $1.70(1.53)$ \\
\hline Growth curve & $1.14(1.60)$ & $1.59(1.59)$ & $1.70(1.64)$ & $1.61(1.40)$ \\
\hline Seasonal curve & $1.39(2.02)$ & $1.74(1.95)$ & $2.20(2.13)$ & $2.03(1.84)$ \\
\hline
\end{tabular}

tively. Similarly for $\mathrm{SO}_{2}$, Bahrain is $246 \%$, Kuwait $490 \%$, Qatar $208 \%$, and the UAE $166 \%$ above the average urban level, whilst for $\mathrm{CHOCHO}$, the corresponding values are Bahrain $33 \%$, Kuwait $72 \%$, Qatar $30 \%$, and the UAE $58 \%$. Meanwhile for $\mathrm{HCHO}$, only Qatar at $30 \%$ is prominently above the average urban level, whereas Bahrain is $18 \%$, Kuwait $8 \%$, the UAE $19 \%$, and Yemen 15\%. According to the World Data Bank's (http://data.worldbank.org) 2014 gross domestic product per capita, Bahrain, Kuwait, Qatar, and the UAE were ranked 39th, 22th, 2nd, and 21st, respectively. By comparison, Iraq and Iran were ranked only 109th and 118th. Thus, over this region we find that the more economically developed countries tend to have the highest pollution levels.
Considering average $\mathrm{NO}_{2}$ levels over individual urban locations, we find Kuwait has 25 settlements in the top 50 highest ranked places, whereas Saudi Arabia has 9 locations, Bahrain 5, Iran 5, and the UAE 5. The highest average $\mathrm{NO}_{2}$ columns were found over Funtas (in Kuwait), with a median value of $63 \times 10^{14}$ molecules $\mathrm{cm}^{-2}$. Funtas is one of several coastal settlements adjacent to the Mina Al-Ahmadi and Mina Abdullah refineries, which all have high average $\mathrm{NO}_{2}$ levels. These two refineries had median vertical column levels of $55.07 \times 10^{14}$ molecules $\mathrm{cm}^{-2}$, which were the highest of all refineries. Similarly, the adjacent Mina Al-Ahmadi port had the highest columns over all ports (of $64.11 \times 10^{14}$ molecules $\mathrm{cm}^{-2}$ ). Thus, this general area is a particularly intense $\mathrm{NO}_{2}$ hotspot, as indi- 
Table 2. Statistical summary of the SAO HCHO vertical column density (VCD) analysis conducted at an approximate $10 \mathrm{~km}$ radius over the target locations. Statistical values are shown for those locations which have a real VCD trend, i.e. those locations without a corresponding trend in either the air mass factor (AMF), cloud fraction (CFR), cloud-top pressure (CTP), or number of samples (SAM). Values in parentheses correspond to statistics for all locations of a given category. VCD values are given in $10^{15}$ molecules $\mathrm{cm}^{-2}$, and IQR is the interquartile range.

\begin{tabular}{|c|c|c|c|c|}
\hline & Urban & Refinery & Oil ports & Power plants \\
\hline \# locations & 818 & 41 & 18 & 155 \\
\hline \multicolumn{5}{|c|}{ \# locations with trends } \\
\hline VCD & 63 & 13 & 6 & 40 \\
\hline VCD and AMF & 9 & 1 & 0 & 6 \\
\hline VCD and CFR & 8 & 4 & 0 & 9 \\
\hline VCD and CTP & 0 & 0 & 0 & 0 \\
\hline VCD and SAM & 16 & 4 & 2 & 6 \\
\hline VCD only & 34 & 6 & 4 & 26 \\
\hline \multicolumn{5}{|l|}{ Observed VCD } \\
\hline Median & $4.36(3.73)$ & $3.95(4.12)$ & $4.51(4.32)$ & $4.13(3.70)$ \\
\hline IQR & $1.03(0.53)$ & $0.67(0.78)$ & $0.80(0.51)$ & $0.88(0.95)$ \\
\hline Maximum & $8.99(10.49)$ & $7.95(9.10)$ & $8.58(8.91)$ & $8.89(9.22)$ \\
\hline Minimum & $-0.80(-3.11)$ & $0.84(-1.53)$ & $1.00(0.15)$ & $-0.80(-1.53)$ \\
\hline \multicolumn{5}{|c|}{ Seasonal amplitude } \\
\hline Median & $3.19(3.13)$ & $2.85(3.27)$ & $3.45(3.43)$ & $3.07(3.02)$ \\
\hline IQR & $0.85(1.09)$ & $0.65(1.15)$ & $0.70(1.31)$ & $0.69(0.95)$ \\
\hline Maximum & $4.15(5.65)$ & $3.27(4.54)$ & $4.08(4.40)$ & $4.54(4.89)$ \\
\hline Minimum & $1.51(1.37)$ & $2.46(1.55)$ & $3.17(2.33)$ & $1.83(1.20)$ \\
\hline \multicolumn{5}{|l|}{ Linear trend } \\
\hline Median & $0.11(0.02)$ & $0.12(0.07)$ & $0.14(0.08)$ & $0.13(0.04)$ \\
\hline IQR & $0.04(0.06)$ & $0.05(0.06)$ & $0.04(0.06)$ & $0.06(0.09)$ \\
\hline Maximum & $0.22(0.22)$ & $0.15(0.18)$ & $0.16(0.16)$ & $0.22(0.22)$ \\
\hline Minimum & $0.09(-0.12)$ & $0.07(-0.02)$ & $0.11(-0.01)$ & $0.08(-0.11)$ \\
\hline \multicolumn{5}{|l|}{ Growth rate } \\
\hline Median & $0.13(0.01)$ & $0.08(0.08)$ & $0.15(0.10)$ & $0.16(0.05)$ \\
\hline IQR & $0.09(0.10)$ & $0.04(0.10)$ & $0.06(0.14)$ & $0.11(0.13)$ \\
\hline Maximum & $0.33(0.33)$ & $0.15(0.26)$ & $0.16(0.18)$ & $0.32(0.32)$ \\
\hline Minimum & $-0.00(-0.50)$ & $0.02(-0.06)$ & $0.08(-0.04)$ & $0.02(-0.15)$ \\
\hline \multicolumn{5}{|l|}{ Median errors } \\
\hline Linear trend & $0.05(0.05)$ & $0.04(0.05)$ & $0.05(0.05)$ & $0.05(0.05)$ \\
\hline Trend curve & $0.19(0.23)$ & $0.19(0.20)$ & $0.20(0.21)$ & $0.20(0.21)$ \\
\hline Smoothed curve & $0.30(0.35)$ & $0.30(0.32)$ & $0.31(0.32)$ & $0.31(0.32)$ \\
\hline Growth curve & $0.27(0.32)$ & $0.27(0.29)$ & $0.28(0.29)$ & $0.28(0.29)$ \\
\hline Seasonal curve & $0.36(0.41)$ & $0.36(0.38)$ & $0.36(0.38)$ & $0.37(0.38)$ \\
\hline
\end{tabular}

cated in Fig. 1, due to the close proximity of several emission sources. For comparison, the highest $\mathrm{NO}_{2}$ columns over power plants were found at the Tarasht Shahid Firouzi power station near Tehran, which had a median level of $74.18 \times 10^{14}$ molecules $\mathrm{cm}^{-2}$.

For HCHO, Iran with 16 locations, Yemen 13, and Saudi Arabia 6 dominated the top-50 ranked urban settlements. The five locations with the highest median values were located in Yemen, along its western coast, with the highest columns found over al-Marawiah, which had an average value of $5.28 \times 10^{15}$ molecules $\mathrm{cm}^{-2}$. Over refineries, the highest median HCHO columns of $4.86 \times 10^{15}$ molecules $\mathrm{cm}^{-2}$ were detected at the Umm Said refinery in Qatar. In addition, 6 of the highest 10 ranked power plants were also located in Qatar, particularly those near Doha and Mesaieed. However, higher median column values of 4.99 and $5.03 \times 10^{15}$ molecules $\mathrm{cm}^{-2}$ were found over the Bandar-e Khomeini port and the Petroshimi and Bandar Imam power plants, respectively. Both of these sites are located close to the Bandar Imam Petrochemical facility in south Iran, which may indicate a potentially strong VOC source.

The top-50 ranked urban locations for $\mathrm{SO}_{2}$ were dominated by Kuwait (26 locations) and Iran (13 locations). The highest median level of $0.73 \mathrm{DU}$ was found at Rafsanjan (Iran), which is located close to the Sarcheshmeh copper mine and smelter facility. The coastal settlements adjacent near the Shuaiba, Mina Al-Ahmadi, and Mina Abdullah refineries (in Kuwait) again had high pollutant levels, typi- 
Table 3. Statistical summary of the NASA $\mathrm{SO}_{2}$ vertical column density (VCD) analysis conducted at an approximate $10 \mathrm{~km}$ radius over the target locations. Statistical values are shown for those locations which have a real VCD trend, i.e. those locations without a corresponding trend in either the cloud fraction (CFR), cloud-top pressure (CTP), or number of samples (SAM). Values in parentheses correspond to statistics for all locations of a given category. VCD values are given in DU, and IQR is the interquartile range.

\begin{tabular}{|c|c|c|c|c|}
\hline & Urban & Refinery & Oil ports & Power plants \\
\hline \# locations & 818 & 41 & 18 & 155 \\
\hline \multicolumn{5}{|c|}{ \# locations with trends } \\
\hline VCD & 24 & 3 & 3 & 14 \\
\hline VCD and AMF & 0 & 0 & 0 & 0 \\
\hline VCD and CFR & 0 & 0 & 0 & 0 \\
\hline VCD and CTP & 0 & 0 & 0 & 0 \\
\hline VCD and SAM & 6 & 0 & 1 & 5 \\
\hline VCD only & 18 & 3 & 2 & 9 \\
\hline \multicolumn{5}{|l|}{ Observed VCD } \\
\hline Median & $0.17(0.11)$ & $0.30(0.28)$ & $0.63(0.28)$ & $0.29(0.16)$ \\
\hline IQR & $0.23(0.09)$ & $0.33(0.31)$ & $0.11(0.21)$ & $0.27(0.24)$ \\
\hline Maximum & $1.22(1.79)$ & $1.05(1.85)$ & $1.98(1.98)$ & $1.17(2.22)$ \\
\hline Minimum & $-0.61(-1.36)$ & $-0.22(-0.64)$ & $-0.02(-0.40)$ & $-0.46(-0.46)$ \\
\hline \multicolumn{5}{|c|}{ Seasonal amplitude } \\
\hline Median & $0.33(0.21)$ & $0.36(0.44)$ & $0.55(0.39)$ & $0.37(0.28)$ \\
\hline IQR & $0.21(0.09)$ & $0.13(0.26)$ & $0.11(0.20)$ & $0.19(0.28)$ \\
\hline Maximum & $0.69(1.15)$ & $0.47(1.13)$ & $0.77(0.86)$ & $0.51(1.14)$ \\
\hline Minimum & $0.17(0.09)$ & $0.34(0.16)$ & $0.33(0.20)$ & $0.18(0.12)$ \\
\hline \multicolumn{5}{|l|}{ Linear trend } \\
\hline Median & $0.021(-0.002)$ & $0.028(0.001)$ & $-0.041(-0.002)$ & $0.026(-0.001)$ \\
\hline IQR & $0.023(0.008)$ & $0.022(0.023)$ & $0.009(0.025)$ & $0.046(0.011)$ \\
\hline Maximum & $0.044(0.044)$ & $0.042(0.042)$ & $-0.024(0.028)$ & $0.028(0.031)$ \\
\hline Minimum & $-0.024(-0.041)$ & $0.019(-0.016)$ & $-0.059(-0.059)$ & $-0.023(-0.023)$ \\
\hline \multicolumn{5}{|l|}{ Growth rate } \\
\hline Median & $0.015(-0.002)$ & $0.036(0.003)$ & $-0.052(-0.002)$ & $0.005(-0.003)$ \\
\hline IQR & $0.032(0.011)$ & $0.034(0.027)$ & $0.002(0.034)$ & $0.032(0.017)$ \\
\hline Maximum & $0.048(0.051)$ & $0.046(0.046)$ & $-0.049(0.047)$ & $0.036(0.057)$ \\
\hline Minimum & $-0.056(-0.056)$ & $0.012(-0.045)$ & $-0.055(-0.055)$ & $-0.012(-0.039)$ \\
\hline \multicolumn{5}{|l|}{ Median errors } \\
\hline Linear trend & $0.009(0.007)$ & $0.010(0.010)$ & $0.014(0.010)$ & $0.010(0.008)$ \\
\hline Trend curve & $0.039(0.030)$ & $0.042(0.041)$ & $0.062(0.044)$ & $0.039(0.035)$ \\
\hline Smoothed curve & $0.058(0.046)$ & $0.066(0.061)$ & $0.091(0.068)$ & $0.064(0.053)$ \\
\hline Growth curve & $0.056(0.042)$ & $0.060(0.058)$ & $0.087(0.063)$ & $0.056(0.050)$ \\
\hline Seasonal curve & $0.070(0.055)$ & $0.079(0.072)$ & $0.110(0.081)$ & $0.075(0.064)$ \\
\hline
\end{tabular}

cally $0.65-0.68$ DU. Similarly, the oil ports of Kharg Island (in the Gulf) and Jeddah terminal also have high levels of 0.85 and $0.76 \mathrm{DU}$. Over power plants, the highest average levels were found over Mobin Petroshimi open cycle gas turbine (OCGT) facility and the Asalooyeh OCGT near Bushehr (Iran), with levels of 1.00 and $0.98 \mathrm{DU}$, respectively.

The highest average $\mathrm{CHOCHO}$ values over urban areas were found mostly in Iran (17 locations), Saudi Arabia (13), and Kuwait (17). The cities of Mecca and Tehran have the largest average levels of 44.32 and $39.44 \times 10^{13}$ molecules $\mathrm{cm}^{-2}$, respectively. The highest levels over refineries are found at Tehran $\left(34.87 \times 10^{13}\right.$ molecules $\left.\mathrm{cm}^{-2}\right)$ and the three main coastal Kuwait refineries of Shuaiba, Mina Al-Ahmadi, and Mina Abdullah $\left(30.34-30.80 \times 10^{13}\right.$ molecules $\left.\mathrm{cm}^{-2}\right)$.
The oil port of Mina Al-Ahmadi also has the highest median level of $30.48 \times 10^{13}$ molecules $\mathrm{cm}^{-2}$. The Mecca OCGT power plant recorded the highest level of $43.81 \times 10^{13}$ molecules $\mathrm{cm}^{-2}$; the other notable CHOCHO levels over power facilities were at Tarasht Shahid Firouzi and Besat (in Tehran), with columns of 42.72 and $39.85 \times 10^{13}$ molecules $\mathrm{cm}^{-2}$, respectively.

\subsection{Observed maximum pollution levels}

We find that median maximum values range from $41-79 \%$ above the overall median $\mathrm{VCD}$ for $\mathrm{NO}_{2}$ (and are highest over oil ports), 68-92\% for HCHO (highest over oil ports), 118 $135 \%$ for $\mathrm{CHOCHO}$ (highest over refineries), and 93-318\% for $\mathrm{SO}_{2}$ (highest over refineries). However, the actual max- 
Table 4. Statistical summary of the BIRA CHOCHO vertical column density (VCD) analysis conducted at an approximate $10 \mathrm{~km}$ radius over the target locations. Statistical values are shown for those locations which have a real VCD trend, i.e. those locations without a corresponding trend in either the air mass factor (AMF), cloud fraction (CFR), cloud-top pressure (CTP), or number of samples (SAM). Values in parentheses correspond to statistics for all locations of a given category. VCD values are given in $10^{13}$ molecules cm ${ }^{-2}$, and IQR is the interquartile range. Values which cannot be computed are represented by NaN (not a number).

\begin{tabular}{|c|c|c|c|c|}
\hline & Urban & Refinery & Oil ports & Power plants \\
\hline \# locations & 818 & 41 & 18 & 155 \\
\hline \multicolumn{5}{|c|}{ \# locations with trends } \\
\hline VCD & 8 & 0 & 0 & 4 \\
\hline VCD and AMF & 5 & 0 & 0 & 3 \\
\hline VCD and CFR & 1 & 0 & 0 & 1 \\
\hline VCD and CTP & 0 & 0 & 0 & 0 \\
\hline VCD and SAM & 1 & 0 & 0 & 0 \\
\hline VCD only & 1 & 0 & 0 & 1 \\
\hline \multicolumn{5}{|l|}{ Observed VCD } \\
\hline Median & $18.22(16.18)$ & $\mathrm{NaN}$ (19.95) & $\mathrm{NaN}(20.84)$ & $18.26(17.88)$ \\
\hline IQR & $\mathrm{NaN}(4.58)$ & $\mathrm{NaN}(9.61)$ & $\mathrm{NaN}(8.72)$ & $\mathrm{NaN}(8.60)$ \\
\hline Maximum & $33.76(112.10)$ & $\mathrm{NaN}(63.18)$ & $\mathrm{NaN}(57.19)$ & $35.50(80.37)$ \\
\hline Minimum & $0.18(-66.32)$ & $\mathrm{NaN}(-23.96)$ & $\mathrm{NaN}(-21.89)$ & $2.63(-44.75)$ \\
\hline \multicolumn{5}{|c|}{ Seasonal amplitude } \\
\hline Median & $9.50(15.03)$ & $\mathrm{NaN}(16.48)$ & $\mathrm{NaN}(14.38)$ & $11.77(16.32)$ \\
\hline IQR & $\mathrm{NaN}(6.54)$ & $\mathrm{NaN}(4.78)$ & $\mathrm{NaN}(4.80)$ & $\mathrm{NaN}(5.74)$ \\
\hline Maximum & $9.50(44.53)$ & $\mathrm{NaN}(28.34)$ & $\mathrm{NaN}(21.10)$ & $11.77(32.14)$ \\
\hline Minimum & $9.50(8.89)$ & $\mathrm{NaN}(9.56)$ & $\mathrm{NaN}(9.93)$ & $11.77(9.12)$ \\
\hline \multicolumn{5}{|l|}{ Linear trend } \\
\hline Median & $-0.83(-0.22)$ & $\mathrm{NaN}(-0.05)$ & $\mathrm{NaN}(-0.01)$ & $-0.88(-0.10)$ \\
\hline IQR & $\mathrm{NaN}(0.66)$ & $\mathrm{NaN}(0.49)$ & $\mathrm{NaN}(0.53)$ & $\mathrm{NaN}(0.57)$ \\
\hline Maximum & $-0.83(3.02)$ & $\mathrm{NaN}(0.40)$ & $\mathrm{NaN}(0.30)$ & $-0.88(0.87)$ \\
\hline Minimum & $-0.83(-1.38)$ & $\mathrm{NaN}(-1.03)$ & $\mathrm{NaN}(-0.77)$ & $-0.88(-1.29)$ \\
\hline \multicolumn{5}{|l|}{ Growth rate } \\
\hline Median & $-0.16(-0.38)$ & $\mathrm{NaN}(-0.12)$ & $\mathrm{NaN}(-0.13)$ & $-1.46(-0.22)$ \\
\hline IQR & $\mathrm{NaN}(1.06)$ & $\mathrm{NaN}(0.98)$ & $\mathrm{NaN}(0.83)$ & $\mathrm{NaN}(1.10)$ \\
\hline Maximum & $-0.16(3.85)$ & $\mathrm{NaN}(1.26)$ & $\mathrm{NaN}(0.83)$ & $-1.46(2.05)$ \\
\hline Minimum & $-0.16(-2.96)$ & $\mathrm{NaN}(-1.70)$ & $\mathrm{NaN}(-1.52)$ & $-1.46(-1.95)$ \\
\hline \multicolumn{5}{|l|}{ Median errors } \\
\hline Linear trend & $0.42(0.58)$ & $\mathrm{NaN}(0.53)$ & $\mathrm{NaN}(0.50)$ & $0.44(0.55)$ \\
\hline Trend curve & $1.79(2.49)$ & $\mathrm{NaN}(2.28)$ & $\mathrm{NaN}(2.11)$ & $1.83(2.41)$ \\
\hline Smoothed curve & $2.84(3.95)$ & $\mathrm{NaN}(3.59)$ & $\mathrm{NaN}(3.38)$ & $2.79(3.66)$ \\
\hline Growth curve & $2.53(3.52)$ & $\mathrm{NaN}(3.22)$ & $\mathrm{NaN}(2.98)$ & $2.58(3.40)$ \\
\hline Seasonal curve & $3.35(4.68)$ & $\mathrm{NaN}(4.23)$ & $\mathrm{NaN}$ (3.99) & $3.34(4.38)$ \\
\hline
\end{tabular}

imum values observed can be substantially higher. For example, the three highest $\mathrm{NO}_{2}$ columns were found at (1) the 247.5MW Oil Besat Thermal Power Plant in Tehran, Iran $\left(189.85 \times 10^{14}\right.$ molecules $\mathrm{cm}^{-2}, 604 \%$ above overall median VCD), (2) the Tarasht Shahid Firouzi power plant also in Tehran $\left(167.78 \times 10^{14}\right.$ molecules $\mathrm{cm}^{-2}, 522 \%$ higher $)$, and (3) over Tehran itself $\left(136.65 \times 10^{14}\right.$ molecules $\mathrm{cm}^{-2}$, $407 \%$ higher). For HCHO, the highest three maximum values are found over the Iranian towns of (1) Shahrekord $\left(10.49 \times 10^{15}\right.$ molecules $\mathrm{cm}^{-2}, 164 \%$ higher than median VCD), (2) Someh Sara $\left(9.89 \times 10^{15}\right.$ molecules $\mathrm{cm}^{-2}$, $149 \%)$, and (3) Fuman $\left(9.83 \times 10^{15}\right.$ molecules $\mathrm{cm}^{-2}$, $148 \%$ ). Whilst for $\mathrm{CHOCHO}$, the highest values are found in the towns of (1) Piranshahr (Iran), which had a maximum of $112.10 \times 10^{13}$ molecules $\mathrm{cm}^{-2}$ (499\%), (2) Tafileh in Jordan $\left(96.57 \times 10^{13}\right.$ molecules $\left.\mathrm{cm}^{-2}, 416 \%\right)$, and (3) Qaemshahr in Iran $\left(80.52 \times 10^{13}\right.$ molecules $\mathrm{cm}^{-2}$, $330 \%$ ). Lastly, for $\mathrm{SO}_{2}$ the three highest maximum values were at the (1 and 2) Mobin Petroshimi OCGT CHP and Asalooyeh OCGT power plants, both in Bushehr (Iran), which had values of $2.22 \mathrm{DU}(957 \%)$ and $2.05(876 \%)$ respectively, and (3) the oil port at Kharg Island, which had a value of $1.98 \mathrm{DU}(843 \%)$.

\subsection{Seasonal variability}

To assess the the seasonal variability over each target, we determined the average peak-to-peak difference of its cor- 
responding time series and used these values to compute the median seasonal amplitude over all locations, within each target category. For $\mathrm{NO}_{2}$, the median seasonal peak-topeak amplitudes are very similar irrespective of target categories. Typical amplitudes of $10-12 \times 10^{14}$ molecules $\mathrm{cm}^{-2}$ are observed (about 39-46\% relative to the overall median). The highest seasonal peak-to-peak amplitude of $66 \times 10^{14}$ molecules $\mathrm{cm}^{-2}$ was found over the Besat Thermal Power Plant in Iran, whereas the lowest seasonal peakto-peak amplitude of $1.49 \times 10^{14}$ molecules $\mathrm{cm}^{-2}$ was determined over Ataq in Yemen. Unlike $\mathrm{NO}_{2}, \mathrm{HCHO}$ exhibits greater seasonal variability (relative to the overall median) with seasonal amplitudes that vary from 3.02$3.43 \times 10^{15}$ molecules $\mathrm{cm}^{-2}$ (or about $60-86 \%$ ), with a high of $5.65 \times 10^{15}$ molecules $\mathrm{cm}^{-2}$ over Dahuk in Iran and a low of $1.20 \times 10^{15}$ molecules $\mathrm{cm}^{-2}$ over the Salalah OCGT power plant in Dhofar (Oman). Similarly, CHOCHO also exhibits large seasonal variability as median amplitudes vary from $14.38-16.48 \times 10^{13}$ molecules $\mathrm{cm}^{-2}$, or $77-88 \%$, with the highest amplitude of $44.53 \times 10^{13}$ molecules $\mathrm{cm}^{-2}$ over Qaemshahr (Iran) and lowest amplitude over Bilin (Palestine) of $8.89 \times 10^{13}$ molecules $\mathrm{cm}^{-2}$. The seasonal variations in $\mathrm{HCHO}$ and $\mathrm{CHOCHO}$ are predominately driven by seasonal variations in biogenic VOC emissions (Müller et al., 2015). Even larger seasonal variability is demonstrated for $\mathrm{SO}_{2}$, as amplitudes range from $0.21-0.44 \mathrm{DU}(100-210 \%)$, with the lowest amplitude of $0.09 \mathrm{DU}$ over Al Ghaydah (Yemen) and highest over 1.15 DU over Shahreza (Iran). We find that the $\mathrm{SO}_{2}$ and $\mathrm{CHOCHO}$ retrievals are generally noisier than their $\mathrm{NO}_{2}$ and $\mathrm{HCHO}$ counterparts, and thus their corresponding time series, even after outlier filtering and residual smoothing, are noisier too (see e.g. Figs. S3-S4). Thus, the higher seasonal amplitudes found in the $\mathrm{CHOCHO}$ and $\mathrm{SO}_{2}$ data may simply reflect larger point-to-point variability in their time series data.

\subsection{Linear trends $\mu$}

For $\mathrm{NO}_{2}$, statistically significant real linear trends were determined for 198 of 818 urban locations (a detection rate of $24 \%$ ). However, in Palestine only 1 out of a potential 274 urban targets had a real trend. Neglecting the Palestine results, in this instance, increases the overall detection rate to $36 \%$. The corresponding "detection percentages" for oil refineries, oil ports, and power plants are 42,33 , and $37 \%$ respectively (Table 1). Urban trends ranged from $-3.05 \pm 0.93$ to $12.23 \pm 1.54 \%$ per year (relative to the observed median column), with the highest trend in Dahuk (Sect. 3.3, Fig. 3). Generally, Iraq and Iran have the highest linear $\mathrm{NO}_{2}$ trends. For example, 5 of the top 7 highest linear trends were found in Iraq, whereas 21 Iranian cities appeared in the top 50 (see Table S2). Overall, the median linear trend is about $3 \% \mathrm{yr}^{-1}$, although, for the top 50 highest ranked locations, the trends were of the order of $2-12 \% \mathrm{yr}^{-1}$, relative to each location's observed median VCD. Only two locations showed a de- crease in $\mathrm{NO}_{2}$ : Aleppo (a.k.a Halab; of $-2.43 \pm 1.06 \% \mathrm{yr}^{-1}$ ) and As-Safira $\left(-3.05 \pm 0.93 \% \mathrm{yr}^{-1}\right)$, both in Syria. On a per-country basis, $75 \%$ of urban targets in Iraq had a real increasing trend, $58 \%$ in Iran, $53 \%$ in Lebanon, $50 \%$ in Qatar, $44 \%$ in Oman, $38 \%$ in Saudi Arabia, $31 \%$ in Jordan, $22 \%$ in Syria, $11 \%$ in Kuwait, $4 \%$ in Israel, $3 \%$ in Yemen, and in Palestine $<1 \%$. No trends were detected in the UAE or Bahrain.

Trends over refineries ranged from about $2-6 \% \mathrm{yr}^{-1}$, with a maximum found over the Daura refinery, near Baghdad; its capacity is smaller than some of the larger refineries, which may indicate the influence of other nearby $\mathrm{NO}_{2}$ sources. For Iran, Iraq, and the UAE, about $60 \%$ of the refineries studied showed an $\mathrm{NO}_{2}$ increase. Trends over oil ports ranged from about $2-9 \% \mathrm{yr}^{-1}$, with the highest trend found over Umm Qasr in Iraq. Trends over power plants ranged from about $2-8 \% \mathrm{yr}^{-1}$, with 5 of the top highest 10 trends found in Iran. The highest trends for power stations were detected over the two Sabiya plants in Kuwait which had trends of $8.13 \pm 0.14 \% \mathrm{yr}^{-1}$. Figure 4, which shows the geographical distribution of $\mathrm{NO}_{2}$ trends (panel a), indicates that there are several local and regional locations where consistent increases of $\mathrm{NO}_{2}$ are observed. For example, these are several targets with increasing trends situated close to Riyadh, Tehran, Baghdad, and Muscat (in Oman), as well as Isfahan and Yazid (both in Iran). Regional trend hot spots include the areas south-west of Tehran and a thin corridor stretching from northern Jordan to Lebanon, passing through southwest Syria.

For HCHO, statistically significant real linear trends were determined for only $4 \%$ of urban locations. The corresponding trend detection percentages are $15 \%$ for oil refineries, $22 \%$ for oil ports, and $17 \%$ for power plants (Table 2). Urban trends ranged from $2-7 \% \mathrm{yr}^{-1}$. The highest absolute linear urban trend was found at al-Wakrah in Qatar (Fig. S2), although this was only about $5 \% \mathrm{yr}^{-1}$ in relative terms; the highest percentage trend was found over Attaif in Saudi Arabia $\left(6.95 \pm 2.42 \% \mathrm{yr}^{-1}\right.$; see Table S2). Generally, Saudi Arabia has the highest number of settlements with increasing HCHO trends (13 of the corresponding 34 trends found). Elsewhere there were 6 trends found in Oman, 5 in Qatar, 3 in Iran, 3 in the UAE, 1 Iraq, and 1 Israel. Only six trends were detected over oil refineries, which ranged from $2-3.5 \% \mathrm{yr}^{-1}$, with a maximum found over the Ruwais refinery in the UAE. Only four trends over oil ports were found, which ranged from $2-4 \% \mathrm{yr}^{-1}$, with the highest trend found over the Ras Laffan port at Al Khawr (Qatar). Trends over power plants ranged from 2-7 $\% \mathrm{yr}^{-1}$ but were only found over Saudi Arabia (8 stations), Iran (5), Qatar (4), and the UAE (5). Figure 4 (panel b) shows that the target locations with trends are mostly found along the western Gulf coast, particularly along the Saudi Arabian coast near Ad-Dammam, and also near Doha in Qatar.

For $\mathrm{SO}_{2}$, very few trends were detected, only $2 \%$ over urban targets, $7 \%$ over refineries, $11 \%$ over oil ports, and $6 \%$ 
(a)

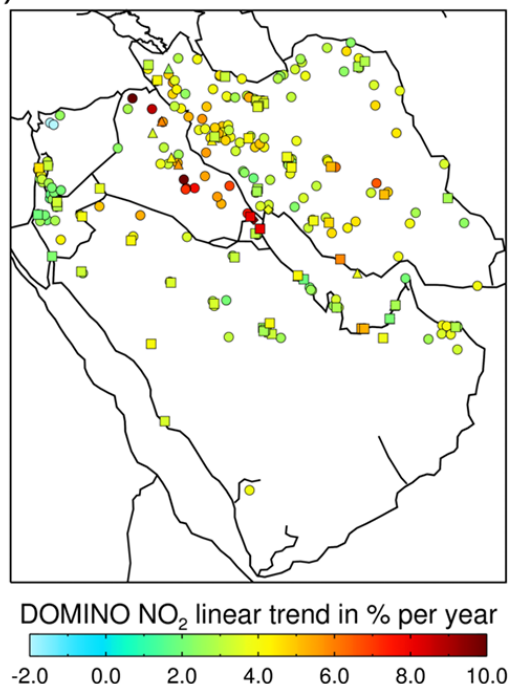

(c)

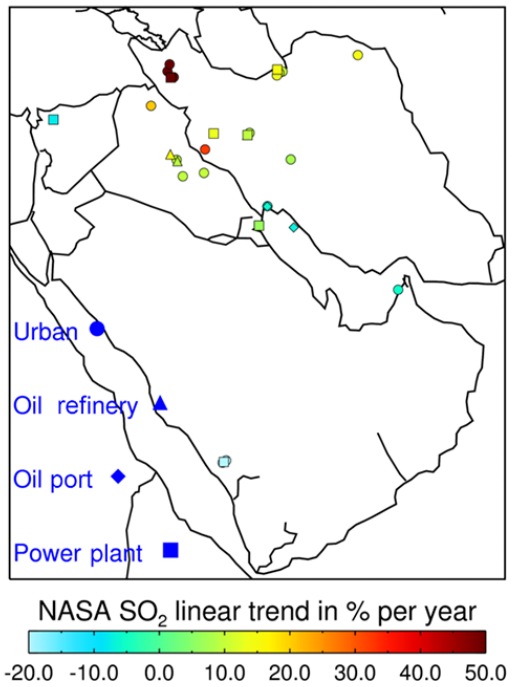

(b)

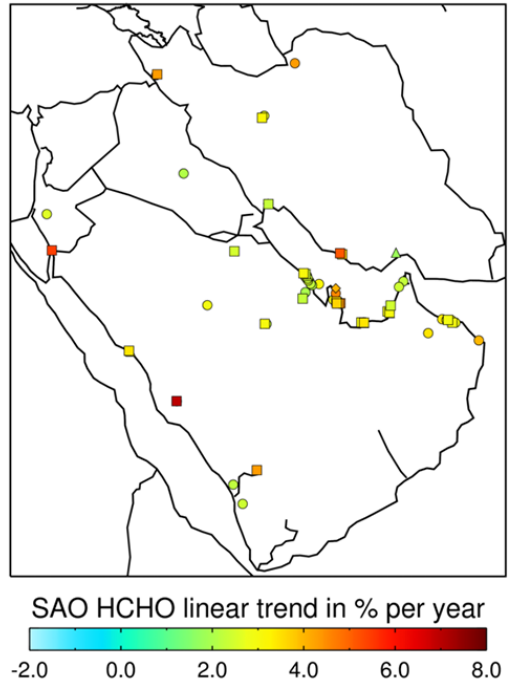

(d)

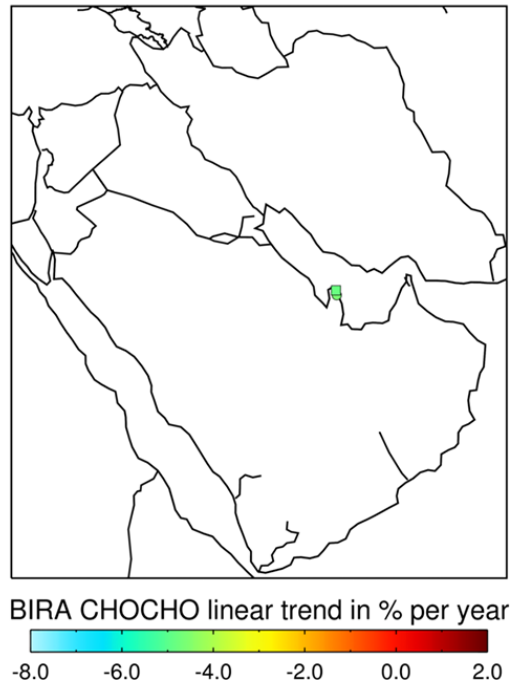

Figure 4. Geographical distribution of locations with statistically significant linear trends in $\mathrm{NO}_{2}(\mathbf{a}), \mathrm{HCHO}(\mathbf{b}), \mathrm{SO}_{2}$ (c), and $\mathrm{CHOCHO}$ (d) expressed in percent per year, relative to each location's 2005-2014 median vertical column.

over power plants (Table 4). Over urban areas, trends ranged from $-61.64 \pm 28.73 \% \mathrm{yr}^{-1}$ in Hamismusayt (also known as Khamis Mushait, Saudi Arabia) to $118.49 \pm 42.78 \% \mathrm{yr}^{-1}$ in Azrashahr (Iran); the latter value is inflated by a median $\mathrm{SO}_{2}$ column of approximately zero over its location. Notably, 11 of the 18 trends were detected in Iran. Over refineries, three trends were detected of about $9-15 \% \mathrm{yr}^{-1}$. Over oil ports, the Iranian oil ports of Bandar-e Khomeini and Kharg Island showed decreases of about $6 \% \mathrm{yr}^{-1}$. Lastly, over power plants 5 locations had decreasing trends of -7 to $-22 \% \mathrm{yr}^{-1}$, and 4 stations had increasing trends of about 6-305 \% $\mathrm{yr}^{-1}$ (again the latter value has a median $\mathrm{SO}_{2}$ column of approximately zero). Figure 4 (panel c) shows the geographical distribution of the $\mathrm{SO}_{2}$ trends; it is evident that several closely located targets exhibit similar trends, particularly (1) near Abba (in south-west Saudi Arabia), (2) around Neka, Sari, and Behshahr in northern Iran, which are close to the Shamid Salimi power plant at Nowzarabad, and (3) Tarbiz, Azrashahr, and Maragheh in Iran.

For CHOCHO only two trends were detected: (1) at AlHawr (Qatar) of $-4.58 \% \mathrm{yr}^{-1}$, and (2) at the Ras Laffan Power plant in Qatar of $-4.83 \% \mathrm{yr}^{-1}$, which are located close to each other (Fig. 4; panel d).

\subsection{Median growth rates $G$}

Figure 5 show the growth rates that correspond to sites with statistically significant linear trends (i.e. where we can be sure that the trend is not attributed to variations in other re- 
(a)

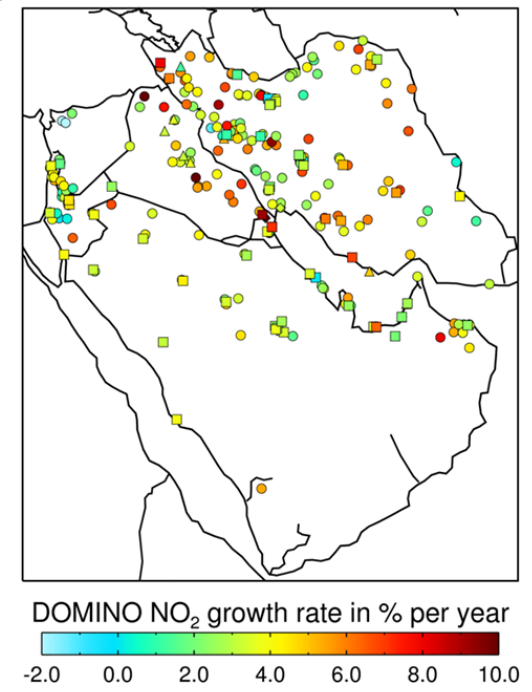

(c)

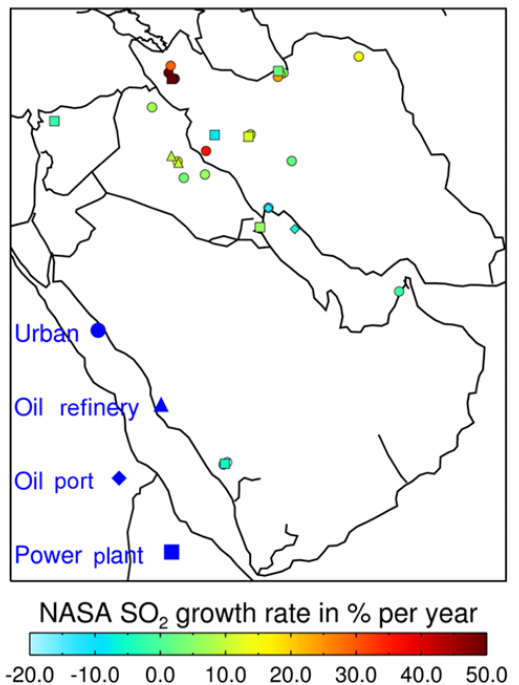

(b)

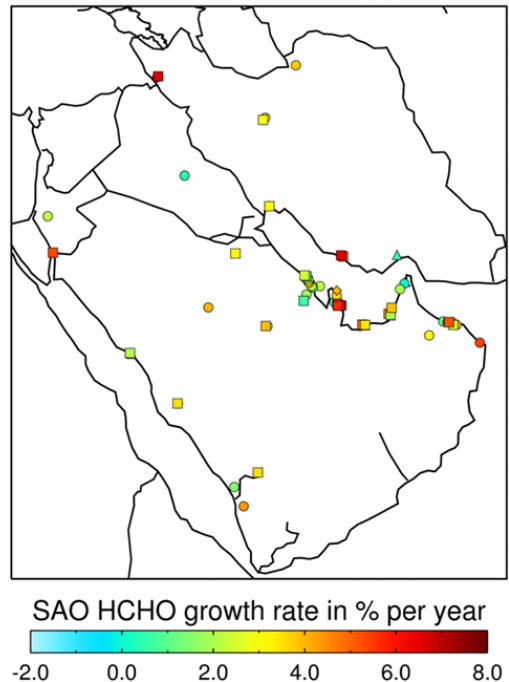

(d)

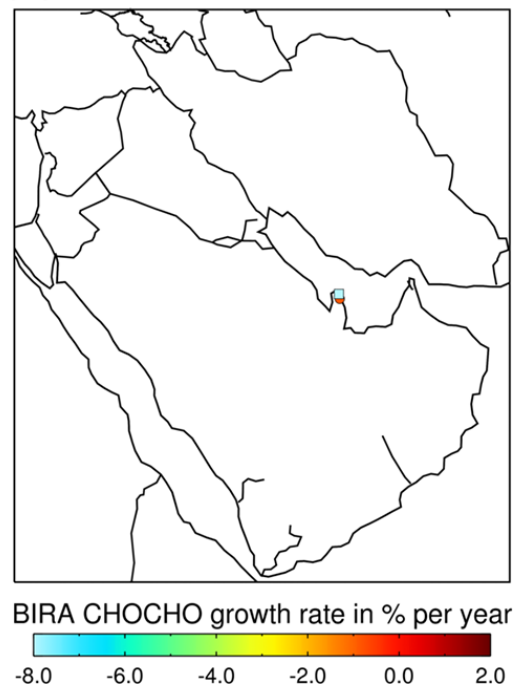

Figure 5. Geographical distribution of locations with statistically significant linear trends in $\mathrm{NO}_{2}(\mathbf{a}), \mathrm{HCHO}(\mathbf{b}), \mathrm{SO}_{2}$ (c), and CHOCHO (c), but here showing the growth rate expressed in percent per year, relative to each location's $2005-2014$ median vertical column.

trieval parameters and where there is enough signal in the data themselves to give a meaningful trend), and Fig. 6 shows their difference, here defined as the linear trend (in $\% \mathrm{yr}^{-1}$ ) minus the growth rate (in $\% \mathrm{yr}^{-1}$ ). Differences between the linear trend and growth rate occur due to the latter tracking inter-annual variations in the data not accounted for in the linear part of Eq. (1) (see Thoning et al., 1989). While the overall median differences are quite small (typically less than $2 \% \mathrm{yr}^{-1}$ ), for individual locations they can be much larger. Typically for $\mathrm{NO}_{2}$ and $\mathrm{HCHO}$, the differences can range between $\pm 5 \% \mathrm{yr}^{-1}$ (Table S3). Such occurrences are nonnegligible. For example, the $\mathrm{NO}_{2}$ linear trend and growth rates over Ibri (in Oman) were about 3 and $8 \% \mathrm{yr}^{-1}$ respectively (i.e. their difference is $5 \% \mathrm{yr}^{-1}$ ). For $\mathrm{SO}_{2}$ the differ- ences can be even more substantial (i.e. tens of percent per year), but this is likely an effect from filtering much noisier fit residuals (e.g. as shown in Fig. S4). Furthermore, Fig. 6 shows that there are no clear spatial patterns or coherence to the geographical distribution of the linear and growth differences. This raises the interesting question for AQ trend studies: should one consider linear changes in a trace gas or use a growth rate? The former does not capture shorter-term variations in growth, but the latter is more susceptible to the choice of fit residual filter and has larger uncertainties. 
(a)

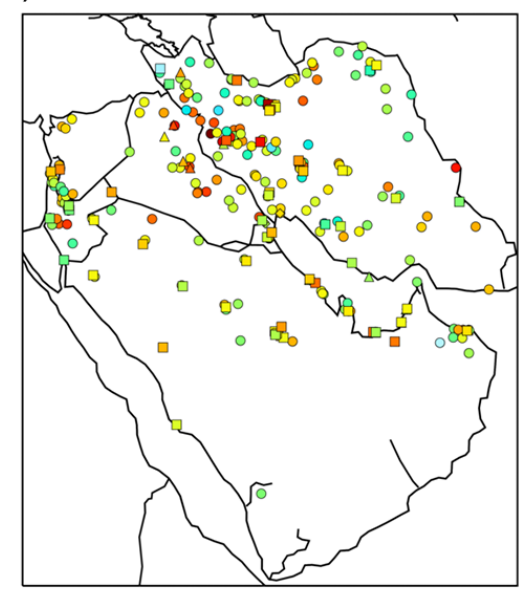

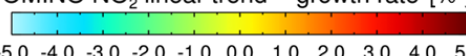

(c)

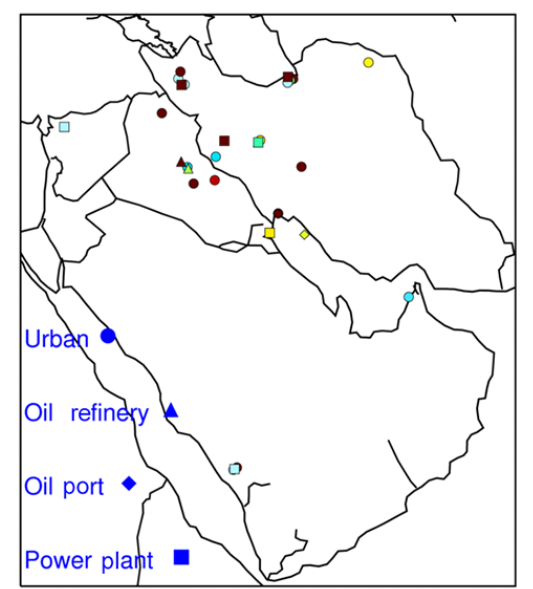

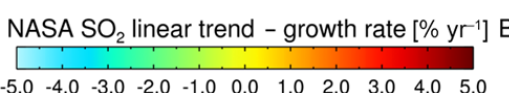

(b)

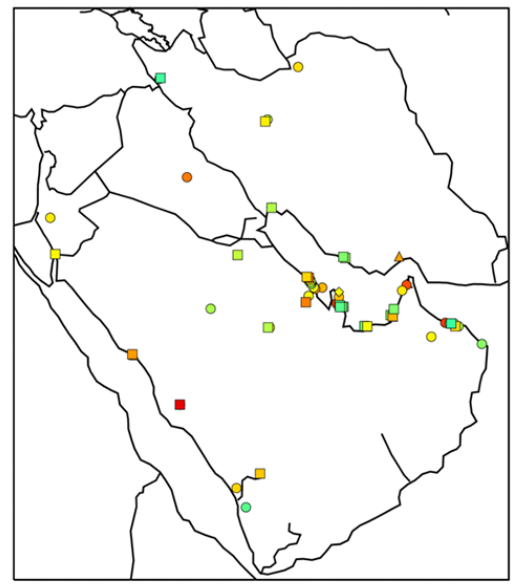

$\mathrm{SAO} \mathrm{HCHO}$ linear trend - growth rate $\left[\% \mathrm{yr}^{-1}\right]$

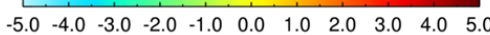

(d)

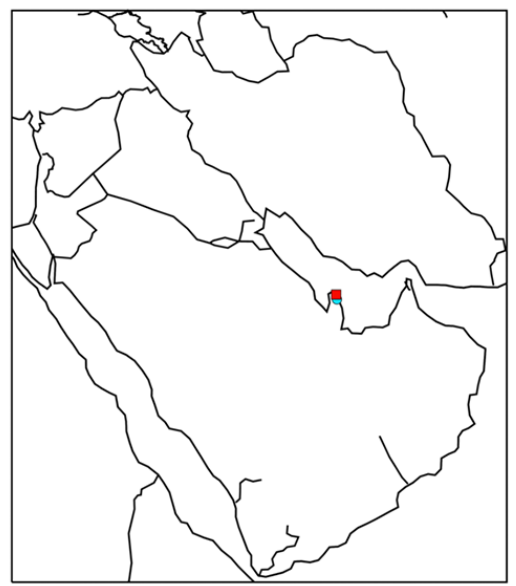

IRA CHOCHO linear trend - growth rate $\left[\% \mathrm{yr}^{-1}\right]$

$\begin{array}{lllllllllll}-5.0 & -4.0 & -3.0 & -2.0 & -1.0 & 0.0 & 1.0 & 2.0 & 3.0 & 4.0 & 5.0\end{array}$

Figure 6. Geographical distribution of locations with statistically significant linear trends in $\mathrm{NO}_{2}(\mathbf{a}), \mathrm{HCHO}(\mathbf{b}), \mathrm{SO}_{2}(\mathbf{c})$, and CHOCHO (d), but here showing the linear trend (in percent per year) minus the growth rate (in percent per year).

\section{Trends: fact or fiction?}

It is, perhaps, tempting to try explain the trends in terms of variations in underlying emissions and/or atmospheric chemistry. However, it seems more prudent to carefully assess the validity of our presented results instead. We do this by examining our analytical uncertainties, by performing a series of sensitivity tests, and by discussing our results in the context of other recent satellite studies.

\subsection{Uncertainties}

Calculated uncertainties in the linear trend and other derived curves mostly reflect the noise of the trace gases time series. For $\mathrm{NO}_{2}$, and considering only those locations with real statistically significant trends, we find that the median uncertainty in the linear trend is about $1 \%$. The median uncertainties are about $4 \%$ for the trend curves, $6-7 \%$ for the smoothed curves, 5-6\% in the growth curves, and about 6 $8 \%$ for the seasonal cycles, respectively. For HCHO, the corresponding values are very similar: $5 \%$ in the trend curves, $7 \%$ in the smoothed, $7 \%$ in the growth, and $9 \%$ in the seasonal curves, with the median uncertainty in the linear trend at about $1 \%$. For $\mathrm{CHOCHO}$, uncertainties are slightly higher, being $10 \%$ in the trend curves, $15 \%$ in the smoothed, $14 \%$ 
in the growth, and $18 \%$ in the seasonal curves. The median uncertainty in the linear trend is about $2 \%$. The uncertainties are noticeably higher for $\mathrm{SO}_{2}$, with errors of $10-23 \%$ in the trend curves, $15-34 \%$ in the smoothed, $14-32 \%$ in the growth, and $18-40 \%$ in the seasonal curves. The median uncertainty in the $\mathrm{SO}_{2}$ linear trend is about 2-5\%. Thus for the most part, the uncertainties in the linear trends are comparable or smaller than than the trends themselves. However, uncertainties in the growth rates are comparable or higher than the derived average growth trends.

\subsection{Sensitivity tests}

Subtle differences in the data analysis approach may affect the choice of locations where trends are detected or may change existing trend directions and magnitudes. Given this situation several additional tests were carried out to determine the sensitivity of our results to various parameters. These are outlined below. Tables S4-S7 record how many trends were now detected in each test and whether or not they were previously detected in the default approach (as outlined in Sect. 3.3).

- Test 1: construct each 10-year time series using a mask of \pm 4 grid cells $(\sim 20 \mathrm{~km}$ radius around each target) instead of the default \pm 2 grid cells $(\sim 10 \mathrm{~km}$ radius around each target).

For $\mathrm{NO}_{2}$, there were 22 and 12 extra trends detected over urban and power plant targets, respectively, compared to our default analysis (shown in Table 1). The number of $\mathrm{NO}_{2}$ trends detected over oil ports and refineries were unchanged. However, some trends previously detected were now missing, compensated by new trends over other locations. For example, in the case of urban targets, 170 locations in this test were also previously detected in the default scenario, but 28 of the previous trends were missing, and 50 new trends were detected (see Table S4). Nevertheless, median linear trends were of similar order (about -2 to $10 \% \mathrm{yr}^{-1}$ ). The highest urban $\mathrm{NO}_{2}$ trends were still at Dahuk and Irbil (in Iraq) but were marginally changed from $12.23 \pm 1.54 \% \mathrm{yr}^{-1}$ to $10.39 \pm 1.42 \% \mathrm{yr}^{-1}$ and from $8.76 \pm 1.17 \% \mathrm{yr}^{-1}$ to $8.18 \pm 1.16 \% \mathrm{yr}^{-1}$, respectively. The Umm Qasr and Zubayr oil terminals were still the highest ranked oil ports, at $8-9 \% \mathrm{yr}^{-1}$. Similarly, the Sabiya CGGT and OCGT power plants still had the highest trend of about $8 \% \mathrm{yr}^{-1}$.

For HCHO this resulted in an extra 25 trends being detected (spread over all categories); nevertheless, the median linear trends were still about $2-3 \% \mathrm{yr}^{-1}$. The majority of trends previously found in the default case were still present in this test. However, notably, the number of detections over oil ports doubled from 4 to 8 , with the highest trend now found over Sitrah in Bahrain at $4.03 \pm 1.14 \%$ (the trends over the Ras Laffan and Al-
Ruwais oil ports were now displaced to second and third highest). That said, both al-Wakarah and Doha still had the highest (absolute) trends for cities (of about 3$4 \% \mathrm{yr}^{-1}$ ), and again the Ras Abu Fontas OCGT power plant in Doha (Qatar) also topped the highest ranked trends over power stations.

For $\mathrm{SO}_{2}$ the highest urban trends were still over Ilam and Tabriz (Iran) and also Baghdad and Irbil (Iraq). Although 18 urban trends were still detected, only 9 were previously found in the default scenario (including those over Sari, Neka, and Maragheh), thus 9 new trend locations were found. Over oil ports the highest trend was now at Umm Qasr $\left(23.09 \pm 5.87 \% \mathrm{yr}^{-1}\right)$, as a trend was not detected at Bandar-e Khomeini (BIK); Kharg Island still reported a decrease of about $-6 \% \mathrm{yr}^{-1} . \mathrm{SO}_{2}$ trends were found over the same three refineries and were still about $9-12 \% \mathrm{yr}^{-1}$. Median trends over urban areas changed from 9.8 to $12.0 \% \mathrm{yr}^{-1}$, but refineries and power plants remained at about 9 and $6 \% \mathrm{yr}^{-1}$, respectively. The Sabiya CGGT and OCGT power plants in Kuwait were still the highest-ranked trends.

For CHOCHO, in addition to the trend of alHawr, only an extra urban trend at Shushtar (Iran) of $-5.33 \pm 2.58 \% \mathrm{yr}^{-1}$ was detected. An additional trend at the Ras Laffan (Qatar) refinery of about $-4.27 \pm 1.91 \% \mathrm{yr}^{-1}$ was also found; the trend over the Ras Laffan power stations was also present as in the default scenario.

In summary, although increasing the averaging radius to $\sim 20 \mathrm{~km}$ around each target has a small impact on overall median trends, it can result in differences at individual locations. Generally however, most of the trends found in the default approach were still present.

- Test 2: use of different cloud fraction filters.

For this test, we used only $\mathrm{OMI} \mathrm{NO}_{2}$ and $\mathrm{HCHO}$ observations with a cloud fraction $\leq 40 \%$ in the analysis; $\mathrm{CHOCHO}$ and $\mathrm{SO}_{2}$ and were untested, as the use of a strict cloud threshold is advised (Krotkov, 2014).

For $\mathrm{NO}_{2}$, there were 45 fewer trends detected in total (mostly over urban locations, 165 compared to 198 previously). The majority of trends in the default analysis were still present - hence the relative median trends were still about $3-4 \% \mathrm{yr}^{-1}$. Furthermore, the top ten urban ranked trends were also mostly unchanged, as were those over oil ports, refineries, and power plants, compared to the default scenario.

For HCHO there were two less detections in total, with the highest urban trend found over Ardebil (Iran) at $7.06 \pm 2.53 \% \mathrm{yr}^{-1}$. Again the majority of locations with trends were consistent with those detected in the default scenario; hence the median trends are still about $3 \% \mathrm{yr}^{-1}$. 
Thus, in summary, increasing the cloud fraction for $\mathrm{NO}_{2}$ and $\mathrm{HCHO}$ slightly decreases the number of trends found, and, on average, has a small impact on overall median trends. Differences at individual locations can still occur, compared to the default approach.

In another test, we also applied a stricter effective cloud fraction filter of $10 \%$ to all species - for $\mathrm{SO}_{2}$ this correspond to a cloud radiance fraction of $20 \%$ - although this may introduce a clear-sky bias relative to all-sky conditions (Krotkov et al., 2016). This had little impact on $\mathrm{SO}_{2}$, although fewer trends in total were detected for $\mathrm{NO}_{2}$ (232) and $\mathrm{HCHO}$ (59); no trends were found for CHOCHO. Generally, most of the highest ranked trends for each species were very similar to the default scenario. This indicates that a $20 \%$ cloud fraction filter is likely an optimum choice for detecting air-quality trends over this region without affecting trend magnitudes.

- Test 3: use of OMI detector rows totally unaffected by the row anomaly (rows 5-23).

Despite the use of the static masks and OMI level-1B XTrackQualityFlags in the data gridding (Sect. 3.1), statistically significant sampling trends are present for a number of locations where VCD trends occur (Tables 14). Therefore, we repeated our analysis, but using only data from OMI's unaffected rows.

However, despite using data from the unaffected detector rows, we still find sampling trends present in some time series. For example, for $\mathrm{NO}_{2}, 227$ statistically significant VCD trends were now detected in total, but 57 of those had a sampling trend. As a consequence, for $\mathrm{NO}_{2}$ only 136 "real" trends in total were detected (instead of 278; see Table 1); in particular, over 100 fewer trends were found over settlements and nearly half the amount over power plants. Nevertheless, trends were found over the same locations (especially in the top 20 ranked urban) with median trends now at 3.0$6.5 \% \mathrm{yr}^{-1}$ (was 3-4\% $\mathrm{yr}^{-1}$ ). The Daura refinery (near Baghdad) and the Umm Qasr port still had the highest trends of these categories (but now of $5.78 \pm 0.95$ and $7.76 \pm 0.91 \% \mathrm{yr}^{-1}$, respectively).

For HCHO, only 38 trends were detected in total (previous total was 70); in particular, 27 urban and 16 power plant trends previously detected were now missing. Median linear trends were $3.0-5.0 \% \mathrm{yr}^{-1}$, with the highest urban trends now found over Sarepol $\left(7.39 \pm 3.41 \% \mathrm{yr}^{-1}\right)$ and Torbatejam $\left(8.41 \pm 2.60 \% \mathrm{yr}^{-1}\right)$, both located in Iran.

For $\mathrm{SO}_{2}$ there were 7 fewer trends detected in total, but notably 9 of the default 18 urban trends were still detected. Median trends were about -7 to $13 \% \mathrm{yr}^{-1}$ (formerly -7 to $10 \% \mathrm{yr}^{-1}$ ). Urban trends now ranged from about -12 to $150 \% \mathrm{yr}^{-1}$ and power plants -7 to $75 \% \mathrm{yr}^{-1}$. A decrease of about $7 \% \mathrm{yr}^{-1}$ was found over Kharg Island port, as was an increase of $9.69 \pm 2.40 \% \mathrm{yr}^{-1}$ over the Daura refinery.

For CHOCHO, only two trends over the towns of Ardebil (of about $25 \% \mathrm{yr}^{-1}$ ) and Shushtar (of about $\left.-18 \% \mathrm{yr}^{-1}\right)$, both in Iran, were detected.

Thus, in summary, we find that using less observations results in fewer trends being detected (since there are less observations used in the averaging, which increases the noise). Furthermore, we find that use of the unaffected rows results in slightly higher median trends overall. Selection of different detector rows also changes the pixel sizes included in the analysis, which may impact the results.

- Test 4: increased smoothing of gridded monthly averages.

To further reduce noise in the gridded data we increase the degree of smoothing by using a larger Gaussian filter of $0.35^{\circ} \times 0.35^{\circ}$ with a $2 \sigma$ width. This had a small effect on our results, as the total number of trends detected for all species and categories was more or less the same in the default scenario, and nearly all the trends locations in the default scenario are still detected. Median trends were also unchanged.

- Test 5: no filtering for outliers in VCD time series analysis.

Whilst filtering for VCD outliers in the time series fitting is advantageous in improving the modelling fitting, it may also remove genuine data points that may affect trend detection.

For $\mathrm{NO}_{2}$ the number of detections and their locations are approximately the same, albeit with 27 new urban trends replacing 26 default trends. Tehran is now the top-ranked city (in absolute terms), although its relative trend of $8.82 \pm 2.59 \% \mathrm{yr}^{-1}$ is still less than that found at Dahuk $\left(15.86 \pm 2.33 \% \mathrm{yr}^{-1}\right)$. Considering all target categories, we find that median trends range from about -2 to $16 \% \mathrm{yr}^{-1}$ (as opposed to about -3 to $12 \% \mathrm{yr}^{-1}$ ). Similarly for HCHO, the number of detections and their locations are approximately the same, and the range of trends is unchanged.

For the most part $\mathrm{SO}_{2}$ trends are also in the same places, with a few exceptions over urban and power plant targets. Trends over urban and refinery targets cover a higher range -23 to $148 \% \mathrm{yr}^{-1}$ and $10-20 \% \mathrm{yr}^{-1}$, respectively, than previously. This results in higher median values of 14 and $15 \% \mathrm{yr}^{-1}$ for these categories (compared to the default case). Median values over oil ports and power plants are unchanged.

Lastly, for CHOCHO, only one urban trend was now detected over Shushtar (Iran) at $-8.65 \pm 3.83 \% \mathrm{yr}^{-1}$, 
and two extra trends were found over the closely located power plants, both at the Az Zour plant complex in Mina Said (Kuwait), which had a trend of $-3.64 \pm 1.75 \% \mathrm{yr}^{-1}$.

In summary, not filtering for VCD outliers only has a small effect on our results. Typically, most trends in the default scenario are detected, albeit with some changes in trend magnitudes (mostly for $\mathrm{NO}_{2}$ and $\mathrm{SO}_{2}$ ).

- Test 6: focus only on cities with $>500000$ people using a spatial mask of \pm 16 grid cells $(\sim 80 \mathrm{~km}$ radius around each target).

In this test we focused on the integrated signals from large population centres, which correspond to 32 targets only. For $\mathrm{NO}_{2}$ there are 22 trends detected (a detection rate of $69 \%$ ), for $\mathrm{HCHO}$ there were 9 trends (32\% detection rate), and for $\mathrm{SO}_{2} 3$ trends were found (9\% detection rate). No trends were found for $\mathrm{CHOCHO}$.

We find that $\mathrm{NO}_{2}$ trends are similar to those found in the default analysis. For example, trends over Tehran, Baghdad, Riyadh, Kirkuk, Orumiyeh (Iran), Isfahan, and Ad-Dammam are approximately the same, although at Irbil the linear trend is now $6 \% \mathrm{yr}^{-1}$; previously it was about $9 \% \mathrm{yr}^{-1}$.

For HCHO there were three locations which could be compared to the default case. These were: Attaif (now $3 \% \mathrm{yr}^{-1}$ was previously $7 \% \mathrm{yr}^{-1}$ ), Abu Dhabi (now $2 \% \mathrm{yr}^{-1}$ was $3 \% \mathrm{yr}^{-1}$ ), and Ad-dammam (still about $3 \% \mathrm{yr}^{-1}$ ), but there were 6 new trend locations found with trends from 2 to $3 \% \mathrm{yr}^{-1}$, consistent with $\mathrm{HCHO}$ trends over other urban settlements.

For $\mathrm{SO}_{2}$ only Tarbiz has a trend that was previously detected $\left(61 \% \mathrm{yr}^{-1}\right)$ but now with a value of $37 \% \mathrm{yr}^{-1}$. We now find two other trends of about $15 \% \mathrm{yr}^{-1}$ at Kermanshah (Iran) and $22 \% \mathrm{yr}^{-1}$ at al-Mawsil (Mosul, Iraq).

In summary, for $\mathrm{NO}_{2}$ and $\mathrm{HCHO}$, we find that the trend detection percentages (relative to the 32 targets) increase, but generally the trends over co-existing locations found in the default analysis do not really change.

Therefore, whilst different approaches in the time series analysis may, in some cases, affect trends found over individual locations, overall there are a large number of targets (per gas species) where trends of approximately the same magnitude are consistently detected. This gives some level of confidence in the robustness of the trend analysis.

\subsection{Comparative studies}

Another way to corroborate our results is through comparison to other similar independent studies. For example, Duncan et al. (2016) performed $\mathrm{NO}_{2}$ trend analyses for the world's major cities using the official NASA product, as described in Bucsela et al. (2013), available from the NASA Goddard Earth Sciences Data Active Archive Center (http://disc.sci.gsfc.nasa.gov). In that study, monthly mean values were based on the average of OMI data falling within $0.3^{\circ} \times 0.3^{\circ}$ boxes centred over the cities. We find good agreement in trend magnitudes (within cited errors) for Tehran, Baghdad, Kirkuk, Kuwait City, Beirut, Aleppo, Mecca (not classified in our analysis as a real trend), and Jerusalem (not classified here as significant). There is disagreement at Mosul $\left(4.43 \pm 1.18 \% \mathrm{yr}^{-1}\right.$, here $\left.2.14 \pm 1.02 \% \mathrm{yr}^{-1}\right)$, Riyadh $\quad\left(0.00 \pm 1.19 \% \mathrm{yr}^{-1}\right.$, here $\left.3.27 \pm 0.85 \% \mathrm{yr}^{-1}\right)$, Homs $\quad\left(-0.81 \pm 0.99 \% \mathrm{yr}^{-1}\right.$, here $1.26 \pm 0.74 \% \mathrm{yr}^{-1}$ and classified as real but not significant), and Damascus $\left(-3.72 \pm 1.10 \% \mathrm{yr}^{-1}\right.$, here $-0.65 \pm 0.92 \% \mathrm{yr}^{-1}$ and classified as not significant or real). These small discrepancies likely occur because of the different choices of OMI data sets and different analysis methodology.

Furthermore, the analysis of SCIAMACHY $\mathrm{NO}_{2}$ over 2002-2012 by Schneider et al. (2015) revealed relative trends of $3.2 \pm 1.1 \% \mathrm{yr}^{-1}$ over Tehran, $2.1 \pm 1.1 \% \mathrm{yr}^{-1}$ over Riyadh, and $8.5 \pm 1.2 \% \mathrm{yr}^{-1}$ over Baghdad, which are compatible with our $\mathrm{NO}_{2}$ trends. Similarly, a top-down multispecies inversion involving OMI DOMINO $\mathrm{NO}_{2}$ columns by Miyazaki et al. (2016) indicated $\mathrm{NO}_{x}$ emissions trends of $3.7 \% \mathrm{yr}^{-1}$ for Tehran and $4.7 \% \mathrm{yr}^{-1}$ for Kuwait City, which are broadly consistent with our results. However, Miyazaki et al. (2016) also found an emissions trend of $-6.0 \% \mathrm{yr}^{-1}$ for Dubai, whereas we find an $\mathrm{NO}_{2}$ trend of $-0.56 \pm 1.05 \% \mathrm{yr}^{-1}$ (classified as real but not significant).

We have also compared our results with the global catalogue of $\mathrm{SO}_{2}$ emission sources produced by Fioletov et al. (2016). Over the Middle East we were able to identify thirty corresponding targets, for which we compared the linear trends of the derived $\mathrm{SO}_{2}$ emissions to our derived $\mathrm{SO}_{2}$ trace gas trends. We find five locations where the $\mathrm{SO}_{2}$ trends in both studies agree (within errors) and where we class the trends as real and significant. For example, there is excellent agreement at Kharg Island (here $-6.89 \pm 2.20 \% \mathrm{yr}^{-1}$ versus $-7.84 \pm 2.50 \% \mathrm{yr}^{-1}$ ) and the Besat power plant in Tehran (in this study $3.54 \pm 3.35 \% \mathrm{yr}^{-1}$, versus $3.86 \pm 3.61 \% \mathrm{yr}^{-1}$ ). However, we also find good agreement at an additional 16 sites, where we class the trends as real but not significant, thus indicating the good correspondence between the two independent studies.

Lastly, both Lelieveld et al. (2015) and Duncan et al. (2016) have used independent economic and social information to attempt an interpretation of observed changes in OMI $\mathrm{NO}_{2}$ and $\mathrm{SO}_{2}$ over the Middle East. We have further compared our derived trends to the linear growth in the Organization of the Petroleum Exporting Countries' (OPEC) oil production and demand data, and additionally, population, GDP per capita, and energy consumption per capita (EC) data, from the World Data Bank (http://data.worldbank.org). We find such comparisons are, at the very least, difficult to 
interpret. For example, over 2005-2014 Iran's GDP grew by $2.8 \% \mathrm{yr}^{-1}$, inline with the $\mathrm{NO}_{2}$ and $\mathrm{HCHO}$ median linear trends of $2-4 \% \mathrm{yr}^{-1}$, but its oil production fell by $-2.5 \% \mathrm{yr}^{-1}$, conflicting with the increasing OMI trace gas trends found over refineries.

\section{Summary and Outlook}

We have performed a robust and detailed time series analysis on 10 years of OMI trace gas observations of $\mathrm{NO}_{2}, \mathrm{HCHO}$, $\mathrm{SO}_{2}$, and $\mathrm{CHOCHO}$ to assess changes in local air quality for over 1000 urban, oil, and energy target locations over the Middle East during the period 2005-2014.

We find that the highest average pollution levels of $\mathrm{HCHO}$, $\mathrm{SO}_{2}$, and $\mathrm{CHOCHO}$ are over the major oil ports and refineries, compared to urban areas and power plants. For HCHO and $\mathrm{CHOCHO}$, the average trace columns are about 15$25 \%$ higher over the oil ports and refineries, whereas for $\mathrm{SO}_{2}$ the columns are about $60-80 \%$ higher. In contrast, $\mathrm{NO}_{2}$ is found to be slightly higher over the urban areas and oil ports by about $5-15 \%$. The highest average pollution levels over urban settlements are typically in Bahrain, Kuwait, Qatar, and the UAE. Other notable pollutant hotspots include: (1) Kuwait City, Tehran, and Mecca; (2) the west coast of Yemen where $\mathrm{HCHO}$ levels are high; and (3) elevated $\mathrm{SO}_{2}$ near Rasanjan and over Kharg Island. We find that the observed vertical columns can exceed average levels by about 40-320\%, depending on the trace gas species.

Our analysis shows that $\mathrm{NO}_{2}$ linear trends over urban locations range from about -3 to $12 \% \mathrm{yr}^{-1}$, although only two locations showed a decrease in $\mathrm{NO}_{2}$. Linear trends over oil refineries and oil ports are about $2-6 \% \mathrm{yr}^{-1}$ and $2-$ $9 \% \mathrm{yr}^{-1}$, respectively. Trends over power plants range from $2-8 \% \mathrm{yr}^{-1}$, with 5 of the topmost 10 trends found in Iran. For $\mathrm{HCHO}$, we find that urban trends are $2-7 \% \mathrm{yr}^{-1}$. Only six trends of $2-3.5 \% \mathrm{yr}^{-1}$ were detected over oil refineries, and only four trends of $2-4 \% \mathrm{yr}^{-1}$ were detected over oil ports. Trends over power plants ranged from $2-7 \% \mathrm{yr}^{-1}$. The increasing $\mathrm{HCHO}$ trends are mostly found along the western Gulf coast, particularly along the Saudi Arabian coast near Ad-Dammam, and also near Doha in Qatar. Very few $\mathrm{SO}_{2}$ trends were detected. Over urban areas, trends ranged from about -60 to $120 \% \mathrm{yr}^{-1}$, with 11 of the 18 trends being detected in Iran. However, some of the high relative $\mathrm{SO}_{2}$ trends can be attributed to median levels of approximately zero over the location. Over refineries, three trends were detected of about $9-15 \% \mathrm{yr}^{-1}$, whilst the Iranian oil ports of Bandar-e Khomeini and Kharg Island showed decreases of about $6 \% \mathrm{yr}^{-1}$. Apart from two locations, we find that $\mathrm{CHO}-$ $\mathrm{CHO}$ levels are not changing over the Middle East. Derived growth rates are, on average, very similar to the fitted linear trends, although differences can occur for individual locations, particularly for $\mathrm{SO}_{2}$. We find that our derived linear trends are generally consistent with other independent OMI trend studies over this region.

Therefore, based on this analysis, we can conclude that for a large number of locations, air quality has deteriorated over 2005-2014. Whilst effective regulatory measures have been established in some countries, it is clear that effective pollutant emission controls are required to limit the health impact on the region's population. Whether this goal is achievable is an open question, especially in countries experiencing civil unrest (e.g. Iraq, Syria, Yemen, and Palestine) or increasing economic growth (e.g. Iran).

In the near future, the TROPOspheric Monitoring Instrument (TROPOMI), which is expected to be launched in 2017 and has a smaller spatial observational footprint compared to OMI, should further help evaluate changes in air quality at local scales. However, it is important that such future measurements are carefully validated and integrated with in situ measurements and chemical transport models, so that they can be utilised properly to influence air-quality policy decision making in Middle Eastern countries.

Data availability. All data products used in the analysis are freely available online, apart from the OMI CHOCHO data which can be accessed via C. Lerot (christophe.lerot@ aeronomie.be). Please contact the author for access to the time series analysis.

\section{The Supplement related to this article is available online at doi:10.5194/acp-17-4687-2017-supplement.}

Competing interests. The authors declare that they have no conflict of interest.

Acknowledgements. This research used the ALICE and SPECTRE High Performance Computing Facility at the University of Leicester. We acknowledge the free use of DOMINO tropospheric $\mathrm{NO}_{2}$ column data from www.temis.nl and the $\mathrm{HCHO}$ and $\mathrm{SO}_{2}$ data from the NASA OMI portal (http://disc.sci.gsfc.nasa.gov/Aura/data-holdings/OMI).

Edited by: G. de Leeuw

Reviewed by: two anonymous referees

\section{References}

Abdul-Wahab, S. A.: Two case studies of air pollution from Oman and Kuwait, Int. J. Environ. Stud., 66, 179-191, doi:10.1080/00207230903069403, 2009.

Acarreta, J. R., De Haan, J. F., and Stammes, P.: Cloud pressure retrieval using the $\mathrm{O}_{2}-\mathrm{O}_{2}$ absorption band at $477 \mathrm{~nm}$, J. Geophys Res., 109, D05204, doi:10.1029/2003JD003915, 2004.

Balk, D., Deichmann, U., Yetman, G., Pozzi, F., and Hay, S. I., and Nelson, A.: Determining Global Population Distribution: 
Methods, Applications and Data, Adv. Parasit., 62, 119-156, doi:10.1016/S0065-308X(05)62004-0, 2006.

Bey, I., Jacob, D. J., Yantosca, R. M., Logan, J. A., Field, B. D., Fiore, A. M., Li, Q., Liu, H. Y., Mickley, L. J., and Schultz, M. G.: Global modeling of tropospheric chemistry with assimilated meteorology: Model description and evaluation, J. Geophys. Res., 106, 23073-23096, doi:10.1029/2001JD000807, 2001.

Boersma, K. F., Eskes, H. J., Veefkind, J. P., Brinksma, E. J., van der A, R. J., Sneep, M., van den Oord, G. H. J., Levelt, P. F., Stammes, P., Gleason, J. F., and Bucsela, E. J.: Near-real time retrieval of tropospheric $\mathrm{NO}_{2}$ from OMI, Atmos. Chem. Phys., 7, 2103-2118, doi:10.5194/acp-7-2103-2007, 2007.

Boersma, K. F., Braak, R., and van der A, R. J.: Dutch OMI $\mathrm{NO}_{2}$ (DOMINO) data product v2.0, HE5 Data File User Manual, available at: http://www.temis.nl/docs/OMI_NO2_HE5_2. 0_2011.pdf (last access: 7 April 2017), 2011a.

Boersma, K. F., Eskes, H. J., Dirksen, R. J., van der A, R. J., Veefkind, J. P., Stammes, P., Huijnen, V., Kleipool, Q. L., Sneep, M., Claas, J., Leitão, J., Richter, A., Zhou, Y., and Brunner, D.: An improved tropospheric $\mathrm{NO}_{2}$ column retrieval algorithm for the Ozone Monitoring Instrument, Atmos. Meas. Tech., 4, 19051928, doi:10.5194/amt-4-1905-2011, 2011b.

Bovensmann, H., Burrows, J. P., Buchwitz, M., Frerick, J., Nöel, S., Rozanov, V. V., Chance, K. V., and Goede, A.: SCIAMACHY mission objectives and measurement modes, J. Atmos. Sci., 56, 127-150, 1999.

Bucsela, E. J., Krotkov, N. A., Celarier, E. A., Lamsal, L. N., Swartz, W. H., Bhartia, P. K., Boersma, K. F., Veefkind, J. P., Gleason, J. F., and Pickering, K. E.: A new stratospheric and tropospheric $\mathrm{NO}_{2}$ retrieval algorithm for nadir-viewing satellite instruments: applications to OMI, Atmos. Meas. Tech., 6, 26072626, doi:10.5194/amt-6-2607-2013, 2013.

Burrows, J. P., Weber, M., Buchwitz, M., Rozanov, V., LadstätterWeißenmayer, A., Richter, A., Debeek, R., Hoogen, R., Bramstedt, K., Eichmann, K.-U., Eisinger, M., and Perner, D.: The Global Ozone Monitoring Experiment (GOME): Mission Concept and First Scientific Results, J. Atmos. Sci., 56, 151-175, 1999.

Callies, J., Corpaccioli, E., Eisinger, M., Hahne, A., and Lefebvre, A.: GOME-2-Metop's second-generation sensor for operational ozone monitoring, ESA Bull., 28-36, 2006.

De Smedt, I., Stavrakou, T., Müller, J.-F., van der A, R. J., and Van Roozendael, M.: Trend detection in satellite observations of formaldehyde tropospheric columns, Geophys. Res. Lett., 37, L18808, doi:10.1029/2010GL044245, 2010.

De Smedt, I., Stavrakou, T., Hendrick, F., Danckaert, T., Vlemmix, T., Pinardi, G., Theys, N., Lerot, C., Gielen, C., Vigouroux, C., Hermans, C., Fayt, C., Veefkind, P., Müller, J.-F., and Van Roozendael, M.: Diurnal, seasonal and long-term variations of global formaldehyde columns inferred from combined OMI and GOME-2 observations, Atmos. Chem. Phys., 15, 12519-12545, doi:10.5194/acp-15-12519-2015, 2015.

Dentener, F., van Weele, M., Krol, M., Houweling, S., and van Velthoven, P.: Trends and inter-annual variability of methane emissions derived from 1979-1993 global CTM simulations, Atmos. Chem. Phys., 3, 73-88, doi:10.5194/acp-3-73-2003, 2003.

Duncan, B. N., Prados, A. I., Lamsal, L. N., Liu, Y., Streets, D. G., Gupta, P., Hilsenrath, E., Kahn, R. A., Nielsen, J. E.,
Beyersdorf, A. J., Burton, S. P., Fiore, A. M., Fishman, J., Henze, D. K., Hostetler, C. A., Krotkov, N. A., Lee, P., Lin, M., Pawson, S., Pfister, G., Pickering, K. E., Pierce, R. B., Yoshida, Y., and Ziemba, L. D.: Satellite data of atmospheric pollution for U.S. air quality applications: Examples of applications, summary of data end-user resources, answers to FAQs, and common mistakes to avoid, Atmos. Environ., 94, 647-662, doi:10.1016/j.atmosenv.2014.05.061, 2014.

Duncan, B. N., Lamsal, L. N., Thompson, A. M., Yoshida, Y., Lu, Z., Streets, D. G., Hurwitz, M. M., and Pickering, K. E.: A spacebased, high-resolution view of notable changes in urban $\mathrm{NO}_{x}$ pollution around the world (2005-2014), J. Geophys. Res., 121, 976-996, doi:10.1002/2015JD024121, 2016.

Dutch Space: GDPS Input/Output Data Specification (IODS) Vol. 2, SD-OMIE-7200-DS-467, available at: https://disc.gsfc.nasa.gov/Aura/data-holdings/OMI/documents/ v003/RD01_SD467_IODS_Vol_2_issue8.pdf (last access: 7 April 2017), 2009.

Fioletov, V. E., McLinden, C. A., Krotkov, N., Moran, M. D., and Yang, K.: Estimation of $\mathrm{SO}_{2}$ emissions using OMI retrievals, Geophys. Res. Lett., 38, 121811, doi:10.1029/2011GL049402, 2011.

Fioletov, V. E., McLinden, C. A., Krotkov, N., Li, C., Joiner, J., Theys, N., Carn, S., and Moran, M. D.: A global catalogue of large $\mathrm{SO}_{2}$ sources and emissions derived from the Ozone Monitoring Instrument, Atmos. Chem. Phys., 16, 11497-11519, doi:10.5194/acp-16-11497-2016, 2016.

Furman, H. and Hadar, K.: Dust Storms in the Middle East: Sources of Origin and Their Temporal Characteristics, Indoor Built Environ., 12, 419-426, doi:10.1177/1420326X03037110, 2003.

Gardiner, T., Forbes, A., de Mazière, M., Vigouroux, C., Mahieu, E., Demoulin, P., Velazco, V., Notholt, J., Blumenstock, T., Hase, F., Kramer, I., Sussmann, R., Stremme, W., Mellqvist, J., Strandberg, A., Ellingsen, K., and Gauss, M.: Trend analysis of greenhouse gases over Europe measured by a network of ground-based remote FTIR instruments, Atmos. Chem. Phys., 8, 6719-6727, doi:10.5194/acp-8-6719-2008, 2008.

Ghude, S. D., Fadnavis, S., Beig, G., Polade, S. D., and van der A, R. J.: Detection of surface emission hot spots, trends, and seasonal cycle from satellite-retrieved $\mathrm{NO}_{2}$ over India, J. Geophys. Res., 113, D20305, doi:10.1029/2007JD009615, 2008.

González Abad, G., Liu, X., Chance, K., Wang, H., Kurosu, T. P., and Suleiman, R.: Updated Smithsonian Astrophysical Observatory Ozone Monitoring Instrument (SAO OMI) formaldehyde retrieval, Atmos. Meas. Tech., 8, 19-32, doi:10.5194/amt-8-192015, 2015.

Hains, J. C., Boersma, K. F., Kroon, M., Dirksen, R. J., Cohen, R. C., Perring, A. E., Bucsela, E., Volten, H., Swart, D. P. J., Richter, A., Wittrock, F., Schoenhardt, A., Wagner, T., Ibrahim, O. W., van Roozendael, M., Pinardi, G., Gleason, J. F., Veefkind, J. P., and Levelt, P.: Testing and improving OMI DOMINO tropospheric $\mathrm{NO}_{2}$ using observations from the DANDELIONS and INTEX-B validation campaigns, J. Geophys. Res., 115, d05301, doi:10.1029/2009JD012399, 2010.

Hewson, W., Barkley, M. P., Gonzalez Abad, G., Bösch, H., Kurosu, T., Spurr, R., and Tilstra, L. G.: Development and characterisation of a state-of-the-art GOME-2 formaldehyde air-mass factor algorithm, Atmos. Meas. Tech., 8, 4055-4074, doi:10.5194/amt8-4055-2015, 2015. 
Hilboll, A., Richter, A., and Burrows, J. P.: Long-term changes of tropospheric $\mathrm{NO}_{2}$ over megacities derived from multiple satellite instruments, Atmos. Chem. Phys., 13, 4145-4169, doi:10.5194/acp-13-4145-2013, 2013.

Jin, X. and Holloway, T.: Spatial and temporal variability of ozone sensitivity over China observed from the Ozone Monitoring Instrument, J. Geophys. Res., 120, 7229-7246, doi:10.1002/2015JD023250, 2015.

Kim, K.-H., Kabir, E., and Kabir, S.: A review on the human health impact of airborne particulate matter, Environ. Int., 74, 136-143, doi:10.1016/j.envint.2014.10.005, 2015.

Kleipool, Q. L., Dobber, M. R., de Haan, J. F., and Levelt, P. F.: Earth surface reflectance climatology from 3 years of OMI data, J. Geophys. Res., 113, D18308, doi:10.1029/2008JD010290, 2008.

Kootungal, L.: 2010 WorldWide Refining Survery, Oil Gas J., 6, 1-67, 2010.

Krotkov, N.: OMSO2 Readme File v1.2.0, NASA Goddard Space Flight Centre, USA, 2014.

Krotkov, N. A., McLinden, C. A., Li, C., Lamsal, L. N., Celarier, E. A., Marchenko, S. V., Swartz, W. H., Bucsela, E. J., Joiner, J., Duncan, B. N., Boersma, K. F., Veefkind, J. P., Levelt, P. F., Fioletov, V. E., Dickerson, R. R., He, H., Lu, Z., and Streets, D. G.: Aura OMI observations of regional $\mathrm{SO}_{2}$ and $\mathrm{NO}_{2}$ pollution changes from 2005 to 2015, Atmos. Chem. Phys., 16, 46054629, doi:10.5194/acp-16-4605-2016, 2016.

Lamsal, L. N., Duncan, B. N., Yoshida, Y., Krotkov, N. A., Pickering, K. E., Streets, D. G., and Lu, Z.: U.S. $\mathrm{NO}_{2}$ trends (2005-2013): EPA Air Quality System (AQS) data versus improved observations from the Ozone Monitoring Instrument (OMI), Atmos. Environ., 110, 130-143, doi:10.1016/j.atmosenv.2015.03.055, 2015.

Lelieveld, J., Hoor, P., Jöckel, P., Pozzer, A., Hadjinicolaou, P., Cammas, J.-P., and Beirle, S.: Severe ozone air pollution in the Persian Gulf region, Atmos. Chem. Phys., 9, 1393-1406, doi:10.5194/acp-9-1393-2009, 2009.

Lelieveld, J., Beirle, S., Hörmann, C., Stenchikov, G., and Wagner, T.: Abrupt recent trend changes in atmospheric nitrogen dioxide over the Middle East, Sci. Adv., 1, e1500498, doi:10.1126/sciadv.1500498, 2015.

Lerot, C., Stavrakou, T., De Smedt, I., Müller, J.-F., and Van Roozendael, M.: Glyoxal vertical columns from GOME-2 backscattered light measurements and comparisons with a global model, Atmos. Chem. Phys., 10, 12059-12072, doi:10.5194/acp10-12059-2010, 2010.

Levelt, P. F., van den Oord, G. H. J., Dobber, M. R., Mälkki, A., Visser, H., de Vries, J., Stammes, P., Lundell, J. O. V., and Saari, H.: The Ozone Monitoring Instrument, IEEE T. Geosci. Remote Sens., 44, 1093-1101, doi:10.1109/TGRS.2006.872333, 2006.

Leys, C., Ley, C., Klein, O., Bernard, P., and Licata, L.: Detecting outliers: Do not use standard deviation around the mean, use absolute deviation around the median, J. Exp. Soc. Psychol., 49, 764-766, doi:10.1016/j.jesp.2013.03.013, 2013.

Li, C., Joiner, J., Krotkov, N. A., and Bhartia, P. K.: A fast and sensitive new satellite $\mathrm{SO}_{2}$ retrieval algorithm based on principal component analysis: Application to the ozone monitoring instrument, Geophys. Res. Lett., 40, 6314-6318, doi:10.1002/2013GL058134, 2013.
Liu, J. J., Jones, D. B. A., Worden, J. R., Noone, D., Parrington, M., and Kar, J.: Analysis of the summertime buildup of tropospheric ozone abundances over the Middle East and North Africa as observed by the Tropospheric Emission Spectrometer instrument, J. Geophys. Res., 114, d05304, doi:10.1029/2008JD010993, 2009.

Martin, R. V.: Satellite remote sensing of surface air quality, Atmos. Environ., 42, 7823-7843, doi:10.1016/j.atmosenv.2008.07.018, 2008.

Miyazaki, K., Eskes, H., Sudo, K., Boersma, K. F., Bowman, K., and Kanaya, Y.: Decadal changes in global surface $\mathrm{NO}_{x}$ emissions from multi-constituent satellite data assimilation, Atmos. Chem. Phys., 17, 807-837, doi:10.5194/acp-17-807-2017, 2017.

Modarres, R. and Dehkordi, A.: Daily air pollution time series analysis of Isfahan City, Int. J. Environ. Sci. Tech., 2, 259-267, doi:10.1007/BF03325885, 2005.

Monks, P., Granier, C., Fuzzi, S., Stohl, A., Williams, M., Akimoto, H., Amann, M., Baklanov, A., Baltensperger, U., Bey, I., Blake, N., Blake, R., Carslaw, K., Cooper, O., Dentener, F., Fowler, D., Fragkou, E., Frost, G., Generoso, S., Ginoux, P., Grewe, V., Guenther, A., Hansson, H., Henne, S., Hjorth, J., Hofzumahaus, A., Huntrieser, H., Isaksen, I., Jenkin, M., Kaiser, J., Kanakidou, M., Klimont, Z., Kulmala, M., Laj, P., Lawrence, M., Lee, J., Liousse, C., Maione, M., McFiggans, G., Metzger, A., Mieville, A., Moussiopoulos, N., Orlando, J., O'Dowd, C., Palmer, P., Parrish, D., Petzold, A., Platt, U., Poschl, U., Prevot, A. S. H., Reeves, C., Reimann, S., Rudich, Y., Sellegri, K., Steinbrecher, R., Simpson, D., ten Brink, H., Theloke, J., van der Werf, G., Vautard, R., Vestreng, V., Vlachokostas, C., and von Glasow, R.: Atmospheric composition change - global and regional air quality, Atmos. Environ., 43, 5268-5350, doi:10.1016/j.atmosenv.2009.08.021, 2009.

Monks, P. S., Archibald, A. T., Colette, A., Cooper, O., Coyle, M., Derwent, R., Fowler, D., Granier, C., Law, K. S., Mills, G. E., Stevenson, D. S., Tarasova, O., Thouret, V., von Schneidemesser, E., Sommariva, R., Wild, O., and Williams, M. L.: Tropospheric ozone and its precursors from the urban to the global scale from air quality to short-lived climate forcer, Atmos. Chem. Phys., 15, 8889-8973, doi:10.5194/acp-15-8889-2015, 2015.

MOP-KRG: Building Kurdistan Region of Iraq: The SocioEconomic Infrastructure, Ministry of Planning Kurdistan Regional Government, 2012.

Müller, J.-F. and Stavrakou, T.: Inversion of $\mathrm{CO}$ and $\mathrm{NO}_{x}$ emissions using the adjoint of the IMAGES model, Atmos. Chem. Phys., 5, 1157-1186, doi:10.5194/acp-5-1157-2005, 2005.

Müller, J.-F., Stavrakou, T., Smedt, I. D., and Roozendael, M. V.: VOC emissions in the Middle East from bottom-up inventories $\&$ as seen by OMI, GlobEmission User Consultation Meeting, Doha, Qatar, 24-25 November, 2015.

Munir, S., Habeebullah, T. M., Seroji, A. R., Gabr, S. S., Mohammed, A. M., and Morsy, E. A.: Quantifying temporal trends of atmospheric pollutants in Makkah (1997-2012), Atmos. Environ., 77, 647-655, doi:10.1016/j.atmosenv.2013.05.075, 2013.

Mustafa, Y. T., Ali, R. T., and Saleh, R. M.: Monitoring and Evaluating Land Cover Change in The Duhok City, Kurdistan RegionIraq, by Using Remote Sensing and GIS, International Journal of Engineering Inventions, 1, 28-33, 2012.

Nasralla, M. and Seroji, A.: Primary pollutants and potential photochemical smog formation in Makkah, Saudi Arabia, Arab Gulf J. Sci. Res., 25, 153-161, 2007. 
OCED: The Cost of Air Pollution - Health Impacts of Road Transport, OECD Publishing, doi:10.1787/9789264210448-en, 2014.

Rashki, A., Rautenbach, C., Eriksson, P., Kaskaoutis, D., and Gupta, P.: Temporal changes of particulate concentration in the ambient air over the city of Zahedan, Iran, Air Quality, Atmosphere \& Health, 6, 123-135, doi:10.1007/s11869-011-0152-5, 2013.

Richter, A., Burrows, J. P., Nüß, H., Granier, C., and Niemeier, U.: Increase in tropospheric nitrogen dioxide over China observed from space, Nature, 437, 129-132, doi:10.1038/nature04092, 2005.

Russell, A. R., Valin, L. C., and Cohen, R. C.: Trends in $\mathrm{OMI} \mathrm{NO}_{2}$ observations over the United States: effects of emission control technology and the economic recession, Atmos. Chem. Phys., 12, 12197-12209, doi:10.5194/acp-12-12197-2012, 2012.

Schneider, P. and van der A, R. J.: A global single-sensor analysis of 2002-2011 tropospheric nitrogen dioxide trends observed from space, J. Geophys. Res., 117, d16309, doi:10.1029/2012JD017571, 2012.

Schneider, P., Lahoz, W. A., and van der A, R.: Recent satellitebased trends of tropospheric nitrogen dioxide over large urban agglomerations worldwide, Atmos. Chem. Phys., 15, 12051220, doi:10.5194/acp-15-1205-2015, 2015.

SEDAC: Center for International Earth Science Information Network - CIESIN - Columbia University, International Food Policy Research Institute - IFPRI, The World Bank, and Centro Internacional de Agricultura Tropical - CIAT, 2011. Global Rural-Urban Mapping Project, Version 1 (GRUMPv1): Settlement Points, Palisades, NY: NASA Socioeconomic Data and Applications Center (SEDAC), doi:10.7927/H4M906KR, 2015.

Spurr, R.: Area-weighting tessellation for nadir-viewing spectrometers, Internal Technical Note, Harvard-Smithsonian Centre for Astrophysics, Cambridge, 2003.

Spurr, R.: LIDORT and VLIDORT: Linearized pseudo-spherical scalar and vector discrete ordinate radiative transfer models for use in remote sensing retrieval problems, Light Scattering Reviews, Vol. 3, edited by: Kokhanovsky, A., Springer-Verlag Berlin Heidelberg, 2008.

Streets, D. G., Canty, T., Carmichael, G. R., de Foy, B., Dickerson, R. R., Duncan, B. N., Edwards, D. P., Haynes, J. A., Henze, D. K., Houyoux, M. R., Jacob, D. J., Krotkov, N. A., Lamsal, L. N., Liu, Y., Lu, Z., Martin, R. V., Pfister, G. G., Pinder, R. W., Salawitch, R. J., and Wecht, K. J.: Emissions estimation from satellite retrievals: A review of current capability, Atmos. Environ., 77, 1011-1042, doi:10.1016/j.atmosenv.2013.05.051, 2013.

Thoning, K. W., Tans, P. P., and Komhyr, W. D.: Atmospheric carbon dioxide at Mauna Loa Observatory: 2. Analysis of the NOAA GMCC data, 1974-1985, J. Geophys. Res., 94, 85498565, doi:10.1029/JD094iD06p08549, 1989.

van der A, R. J., Peters, D. H. M. U., Eskes, H., Boersma, K. F., Van Roozendael, M., De Smedt, I., and Kelder, H. M.: Detection of the trend and seasonal variation in tropospheric $\mathrm{NO}_{2}$ over China, J. Geophys. Res., 111, D12317, doi:10.1029/2005JD006594, 2006. van $\operatorname{der}$ A, R. J., Eskes, H. J., Boersma, K. F., van Noije, T. P. C., Van Roozendael, M., De Smedt, I., Peters, D. H. M. U., and Meijer, E. W.: Trends, seasonal variability and dominant $\mathrm{NO}_{x}$ source derived from a ten year record of $\mathrm{NO}_{2}$ measured from space, $\mathrm{J}$. Geophys. Res., 113, d04302, doi:10.1029/2007JD009021, 2008.

Volkamer, R., Baidar, S., Campos, T. L., Coburn, S., DiGangi, J. P., Dix, B., Eloranta, E. W., Koenig, T. K., Morley, B., Ortega, I., Pierce, B. R., Reeves, M., Sinreich, R., Wang, S., Zondlo, M. A., and Romashkin, P. A.: Aircraft measurements of $\mathrm{BrO}$, $\mathrm{IO}$, glyoxal, $\mathrm{NO}_{2}, \mathrm{H}_{2} \mathrm{O}, \mathrm{O}_{2}-\mathrm{O}_{2}$ and aerosol extinction profiles in the tropics: comparison with aircraft-/ship-based in situ and lidar measurements, Atmos. Meas. Tech., 8, 2121-2148, doi:10.5194/amt-8-2121-2015, 2015.

Wang, Y., Beirle, S., lampel, J., Koukouli, M., De Smedt, I., Theys, N., Li, A., Wu, D., Xie, P., Liu, C., Van Roozendael, M., and Wagner, T.: Validation of OMI, GOME-2A and GOME-2B tropospheric $\mathrm{NO}_{2}, \mathrm{SO}_{2}$ and $\mathrm{HCHO}$ products using MAX-DOAS observations from 2011 to 2014 in Wuxi, China, Atmos. Chem. Phys. Discuss., doi:10.5194/acp-2016-735, in review, 2016.

Weatherhead, E. C., Reinsel, G. C., Tiao, G. C., Meng, X.-L., Choi, D., Cheang, W.-K., Keller, T., DeLuisi, J., Wuebbles, D. J., Kerr, J. B., Miller, A. J., Oltmans, S. J., and Frederick, J. E.: Factors affecting the detection of trends: Statistical considerations and applications to environmental data, J. Geophys. Res., 103, 1714917161, doi:10.1029/98JD00995, 1998.

WHO: 7 million premature deaths annually linked to air pollution, Public Health, Social and Environmental Determinants of Health Department, World Health Organisation, 1211 Geneva 27, Switzerland, available at: http://www.who.int/mediacentre/news/ releases/2014/air-pollution/en/ (last access: 7 April 2017), 2014.

Zanis, P., Hadjinicolaou, P., Pozzer, A., Tyrlis, E., Dafka, S., Mihalopoulos, N., and Lelieveld, J.: Summertime free-tropospheric ozone pool over the eastern Mediterranean/Middle East, Atmos. Chem. Phys., 14, 115-132, doi:10.5194/acp-14-115-2014, 2014

Zhu, L., Jacob, D. J., Kim, P. S., Fisher, J. A., Yu, K., Travis, K. R., Mickley, L. J., Yantosca, R. M., Sulprizio, M. P., De Smedt, I., González Abad, G., Chance, K., Li, C., Ferrare, R., Fried, A., Hair, J. W., Hanisco, T. F., Richter, D., Jo Scarino, A., Walega, J., Weibring, P., and Wolfe, G. M.: Observing atmospheric formaldehyde (HCHO) from space: validation and intercomparison of six retrievals from four satellites (OMI, GOME2A, GOME2B, OMPS) with SEAC ${ }^{4}$ RS aircraft observations over the southeast US, Atmos. Chem. Phys., 16, 1347713490, doi:10.5194/acp-16-13477-2016, 2016. 